Dr Jugoslav Kodžopeljić, general-major, dipl. inž.

\section{MODELI SISTEMA KVALITETA NABAVKI I USLUGA PREMA SERIJI STANDARDA ISO (JUS) 9000-9004 I SISTEMSKA RES̈ENJA VOJSKE JUGOSLAVIJE ZA NJIHOVU PODRS̄KU}

\begin{abstract}
Međunarodni standardi ISO 9000-9004 prihvaćeni su kao minimum zahteva za obezbeđenje sistema kvaliteta nabavki i usluga. Radi toga, svaka zemlja mora da obezbedi odgovarajuće metodologije i tehnike da realizuje sve elemente sistema kvaliteta na odgovarajući način.

U ovom članku identifikovani su modeli prema navedenim standardima za nabavke $\mathrm{i}$ usluge, $\mathrm{i}$ izvršena analiza načina nabavke $\mathrm{i}$ vršenja usluga za potrebe Vojske Jugoslavije. Modeli nabavke tehničkih materijalnih sredstava (TMS), naoružanja i vojne opreme (NVO), kao i usluga za Vojsku Jugoslavije, povezani su sa modelima za obezbeđenje sistema kvaliteta prema ISO standardima. Na osnovu toga i postojećih metodologija i tehnika za realizaciju zahteva standarda, prikazana je njihova pokrivenost propisima ili standardima. Pri tome, izvršeno je povezivanje tačaka i podtačaka ISO standarda sa odgovarajućim nosiocima nadležnim za njihovu realizaciju.
\end{abstract}

\section{Uvod}

Kvalitet se, po međunarodnom standardu ISO 8402, koji je prihvaćen i kao domaći, definiše kao skup svih osobina i karakteristika proizvoda i usluga, koji se odnose na njihovu mogućnost da zadovolje utvrđene ili izražene potrebe. Do ove definicije, a posebno njenog sadržaja, u međunarodnoj standardizaciji došlo se posle dugotrajnog razvoja dotične oblasti i usaglašavanja međunarodnih, vladinih i nevladinih, organizacija. Pri tome, polazi se od činjenice da je jedan od osnovnih faktora u poslovanju organizacije (preduzeća, korporacije i sl.) kvalitet njenih proizvoda ili usluga. Naglašen je svetski trend strožih zahteva kupca u pogledu kvaliteta. Došlo se do saznanja da je praćenje tog trenda i stalno poboljšanje kvaliteta proizvoda i usluga uslov da se postigne $i$ održi dobro ekonomsko poslovanje.
Zahteve kupca ili korisnika usluga, proizvođač (isporučilac) želi da zadovolji u celini.

Ovi zahtevi često se specificiraju kao tehničke karakteristike (tehničko-eksploatacioni zahtevi), koje proizvođač želi da ispuni.

Međutim, zahtevi sami po sebi ne mogu predstavljati garanciju da će biti dosledno ispunjeni jer mogu biti nekompletni ili neadekvatni, a može biti i propusta $u$ sistemu projektovanja, $u$ proizvodnji $i$ ispitivanju proizvoda ili vršenju usluga. To je dovelo do razvoja standarda sistema kvaliteta i odgovarajućih uputstava ili modela kojima se dopunjavaju zahtevi za proizvod ili uslugu. Serija međunarodnih do sada izašlih standarda ISO $9000-9004,10011,10012$ i 10013, predstavlja racionalizaciju mnogih i različitih nacionalnih pristupa $u$ ovoj oblasti. 
Važno je napomenuti da za realizaciju pojedinih elemenata tako definisanog sistema kvaliteta moraju da postoje posebni standardi, propisi i uputstva. Neki od njih su već međunarodno standardizovani, a pojedine, svaka zemlja standardizuje ili propisuje za svoje potrebe. Vojska Jugoslavije takođe, za svoje potrebe, razvija posebne propise i standarde.

Međunarodne standarde o sistemu kvaliteta prihvatila je i naša zemlja kao odgovarajuće JUS standarde. Pri tome, postavlja se pitanje kako ih sprovoditi, ko je za to odgovoran po nivoima organizovanja odgovarajućih državnih organa $i$ organa $i$ organizacije u preduzećima koja proizvode ili vrše usluge. Proces organizovanja sistema kvaliteta $u$ našoj privredi i drugim organizacijama je $\mathbf{u}$ toku, pa je veoma značajno odrediti nosioce $i$ metodologiju realizacije pojedinih elemenata iz navedenih međunarodnih standarda $o$ kvalitetu proizvoda i usluga.

Radi toga izvršena je identifikacija modela obezbeđenja kvaliteta proizvoda i usluga prema ISO-JUS standardima, a na osnovu njih, za specifičan sistem kakav je Vojska Jugoslavije, date su odgovarajuće varijante nabavki i vršenja usluga. U odnosu na takvu spregu modela i varijanti nabavki i usluga, za svaku nomenklaturu standarda (element sistema kvaliteta) definisan je postojeći standard ili propis kojim se podržava (propisuje) način realizacije, odnosno ostvarenja tog elementa sistema kvaliteta.

\section{Oblici (modeli) sistema kvaliteta proizvoda i usluga po ISO-JUS standardima}

Cilj serije međunarodnog standarda ISO 9000-9004 nije da uniformiše sisteme kvaliteta koji se primenjuju u proizvodnim i uslužnim organizacijama i preduzećima već da:
- razjasni međusobne veze $i$ razlike osnovnih koncepcija kvaliteta,

- pruži uputstva o pristupu problemu kvaliteta u situaciji kada je kvalitet regulisan ugovorom i kada nije regulisan ugovorom.

Naime, serija međunarodnih standarda predstavlja samo racionalizaciju mnogih i različitih nacionalnih pristupa u oblasti kvaliteta, odnosno u oblastima koje definiše.

Ova značajna činjenica ukazuje da je to minimum koji se mora ostvariti (u zavisnosti od usvojenog modela), a zadatak je proizvođača (isporučioca) da realizuje proizvod odgovarajućeg kvaliteta, ili proizvođača i kupca da se realizuje proizvod ili usluga na nivou ugovora i pri tom postavljenih zahteva $i$ uslova. $U$ obe navedene situacije isporučilac želi da ugradi i održava sistem kvaliteta koji će ojačati njegovu konkurentnost, kao i da postigne potreban kvalitet proizvoda i usluga na ekonomičan način. Kao dodatak tome, u situacijama kada je to regulisano ugovorom, kupac je zainteresovan i za izvesne elemente sistema kvaliteta isporučioca koji utiču na mogućnost isporučioca da razvija, proizvodi $i$ isporučuje proizvode ili vrši usluge u skladu sa njegovim zahtevima i odgovarajućim rizicima. Zbog toga kupac može zahtevati takve ugovorne obaveze iz sistema kvaliteta gde će izvesni elementi sistema kvaliteta biti deo sistema kvaliteta isporučioca.

S druge strane, isporučilac se može naći u obe situacije: da nabavlja neke standardne materijale ili sastavne delove bez ugovorenih zahteva, i da nabavlja sa ugovorenim zahtevima za obezbeđenje kvaliteta. Taj isporučilac može prodavati svoje proizvode u situacijama kada to nije regulisano ugovorom, ali i kada postoje ugovorene obaveze o kvalitetu.

Zbog toga serija međunarodnih ISO standarda daje standardizaciju za dve situacije: 
- ISO 9000 i 9004 daju uputstva svim organizacijama za oblast kvaliteta,

- ISO 9001, 9002 i 9003 daju uputstva kod eksternog obezbeđenja kvaliteta, u situacijama kada je to regulisano ugovorom između isporučioca i kupca.

Načelno, u tim slučajevima, kupac $i$ isporučilac treba da razmotre standarde ISO 9001, 9002 i 9003 (kada se radi o ugovorenim obavezama), da bi odredili koji od ovih međunarodnih standarda najviše odgovara ugovoru i koja specifična prilagođavanja treba izvršiti.

Izbor i primena jednog od modela obezbeđenja kvaliteta, pogodnog za datu situaciju, treba da obezbedi korist i za kupca i za isporučioca (proizvođača). Procenjivanje rizika troškova i koristi za obe strane odrediće obim i prirodu međusobnih informacija i mera koje svaka strana mora preduzeti radi sticanja poverenja da će biti postignut odgovarajući kvalitet proizvoda ili usluge.

\section{Oblici (modeli) obezbeđenja kvaliteta tehničkih materijalnih sredstava, odnosno sredstava naoružanja $i$ vojne opreme}

Tehnička materijalna sredstva, odnosno naoružanje i vojinu opremu, Vojska Jugoslaviie nabavlja na tržištu gotovih proizvoda u zemlji, postavlja proizvođačima sredstava posebne zahteve za razvoj ili nabavlja sredstva iz uvoza kao gotove proizvode ili uz izvesne modifikacije. U svim tim slučajevima, sa proizvođačima, dobavljačima ili uvoznicima zaključuju se odgovarajući ugovori. Znači, u pogledu obezbeđenja kvaliteta tehničkih sredstava radi se o ugovaranju, odnosno eksternom obezbeđenju sistema kvaliteta.

U zavisnosti od načina nabavke tehničkih materijalnih sredstava, do sa- da usvojeni međunarodni (izdati i kao domaći JUS) standardi, omogućavaju različite oblike, odnosno modele za ugovaranje eksternog obezbeđenja kvaliteta. Obezbeđenje sistema kvaliteta sredstava zavisi od funkcionalne ili organizacione sposobnosti pogodne za zaključivanje ugovora sa proizvođačem, isporučiocem ili dobavljačem. U odnosu na to, moguća su sledeća tri modela ugovaranja, odnosno obezbeđenja kvaliteta:

- model koji se koristi kada isporučilac (proizvođač) treba da obezbedi usaglašenost svog sistema kvaliteta sa ugovorom utvrđenim zahtevima za kvalitet kroz nekoliko faza koje mogu obuhvatiti razvoj-projektovanje-proizvodnju-servisiranje (održavanje). Tada se koristi ISO 9001 (Model obezbeđenja kvaliteta u projektovanju, razvoju, proizvodnji, ugradnji i servisiranju);

- model koji se koristi kada isporučilac (proizvođač) treba da obezbedi usaglašenost svog sistema kvaliteta sa ugovorom utvrđenim zahtevima za kvalitet samo u procesu proizvodnje. Tada se koristi ISO 9002 (Model obezbeđenja kvaliteta u proizvodnji i ugradnji);

- model koji se koristi kada isporučilac treba da obezbedi usaglašenost sistema kvaliteta sa ugovorom utvrđenim zahtevima za kvalitet samo $u$ završnoj kontroli i ispitivanju. Tada se koristi ISO 9003 (Model obezbeđenja kvaliteta u završnoj kontroli $\mathrm{i}$ ispitivanju).

U odnosu na iznete činjenice, a radi opremanja Vojske Jugoslavije sredstvima naoružanja i vojne opreme, odnosno tehničkim materijalnim sredstvima, moguće je ugovaranje po sva tri modela obezbeđenja sistema kvaliteta i za obe situacije (nabavka na domaćem tržištu ili iz uvoza).

Pri tome, ako se radi o razvoju sredstava NVO po specifičnim zahtevima VJ, onda se skoro isključivo ko- 
risti prvi model, tj. ugovaranje sistema kvaliteta treba vršiti po standardu ISO 9001. Naravno, ovaj model ce se koristiti ređe kada se radi o uvozu sredstava NVO.

Kada se radi o nabavci tehničkog sredstva koje se već proizvodi, ugovaranje sistema kvaliteta će se obavljati po ISO 9002 ili 9003 . U zavisnosti od poverenja prema proizvođaču i njegovom sistemu kontrole, kao i od sopstvenih potreba za nivoom kvaliteta tehničkih sredstava koja se nabavljaju, ugovoriće se model obezbeđenja kvaliteta samo u završnoj kontroli i ispitivanju po standardu ISO 9003 ili model obezbeđenja kvaliteta $u$ proizvodnji i ugradnji (podrazumeva i završnu kontrolu $\mathfrak{i}$ ispitivanje) po standardu ISO 9002. Iz toga se vidi da je ISO 9002, $u$ izvesnom smislu, dopunski standard modelima ISO 9001 i 9003. Naravno, to se može primeniti i na međusobni odnos sva tri standarda.

Kada se radi o nabavci tehničkih sredstava na tržištu gotovih proizvoda, treba ugovarati sistem kvaliteta samo po ISO 9003 ili ISO 9002 i 9003 . Takav sistem ugovaranja treba primeniti i kod tzv. decentralizovane nabavke tehničkih sredstava, odnosno sredstava opšte namene.

Takođe treba istaći da se pri decentralizovanoj nabavci tehničkih sredstava ili pri nabavci tehničkih sredstava opšte namene može prihvatiti i obezbeđenje sistema kvaliteta po standardima ISO 9000 i 9004 u kojima je definisan opšti model upravljanja kvalitetom i dati elementi sistema kvaliteta kao opšte uputstvo za izbor i primenu modela i elemenata sistema kvaliteta.

Modeli sistema kvaliteta usluga za potrebe Vojske Jugoslavije

Značaj i nastojanje da se organizacije, kompanije, preduzeća i društva podstaknu na kvalitetno izvođenje svo- jih usluga, doveli su do međunarodne standardizacije minimalnog nivoa kvaliteta usluga. U početnoj ISO standardizaciji usluge su samo spominjane, a 1991. godine je izdat poseban standard koji daje smernice za usluge (ISO 9004-2). Taj standard je prihvaćen i kod nas i u primeni je od 1993. godine.

Principi na kojima je definisan ovaj standard uzeti su iz serije standarda ISO 9000-9004. Povod za njegovo prihvatanje je činjenica da greška u kvalitetu usluga može imati negativan uticaj na korisnika usluga, organizaciju, pa i društvo. Takođe, prihvaćeno je da rukovodstvo treba da osigura da se takve greške spreče.

Realizacija i održavanje sistema kvaliteta kod izvršioca usluge zavisi od sistemskog pristupa upravljanju kvalitetom, usmerenog potrebama korisnika. Pri tome, obezbeđenje kvaliteta na svim nivoima i segmentima kod izvršioca usluge, njegovo stalno preispitivanje i usavršavanje zasniva se na povratnoj sprezi korisnikovog shvatanja o obezbeđenoj usluzi.

Uspešan sistem kvaliteta usluga obezbeđuje:

- poboljšanje vršenja usluga i time zadovoljenje potreba korisnika,

- poboljšanje produktivnosti i smanjenje troškova, štu.

- dobijanje više poslova na trži-

Radi postizanja ovih prednosti, sistem kvaliteta usluga mora uključiti i odgovarajuće aspekte vezane za kadrove koji pripremaju ili realizuju usluge.

Standard ISO 9004-2 daje uputstva za uspostavljanje i održavanje sistema kvaliteta usluga unutar organizacije izvršioca usluga. Standard se može primeniti za realizaciju sistema kvaliteta postojećih usluga ili onih koje će se tek realizovati, a obuhvata sve procese neophodne za pružanje efikasne usluge, od marketinga do isporuke pro- 
izvoda, uključujući analize izvršenih usluga.

Koncept, principi i elementi sistema kvaliteta $u$ ovom standardu primenljivi su za sve oblike usluga. Model se može koristiti kako za velike, tako i za male organizacije (razlika je samo u meri primene).

Standard može da se primeni na različite vrste usluga: ugostiteljske, saobraćajne, zdravstvene, održavanje i remont, snabdevanje energijom, trgovinu, finansije, građevinarstvo, obrazovanje, administraciju, tehničke usluge, snabdevanje, i sl.

Vojska Jugoslavije ima potrebe da koristi veliki broj navedenih vrsta usluga. Pri tome, poznato je (propisima je definisano) koja struktura Vojske je kao taktički nosilac zadužena za određenu vrstu usluge. Takođe, određeni su i nosioci ugovaranja po nivoima $\mathrm{i}$ vrstama usluga.

Sumirajući potrebe za uslugama, može se konstatovati da postoje četiri modela:

- model kada jedinice i ustanove VJ koriste usluge izvršioca po obliku i sadržaju, kako se to obavlja i za druge korisnike usluga na tržištu;

- model kada jedinice i ustanove VJ koriste usluge izvršioca koje su prilagođene zahtevima $\mathrm{VJ}$;

- model kada jedinice i ustanove VJ imaju potrebe za korišćenjem specifičnih usluga. Tada se propisuju zahtevi, a izvršilac se osposobljava za izvođenje takve usluge;

- kao poseban model može se tretirati zadatak tzv. osvajanja neke usluge (na primer, osvajanje generalnog remonta). To je slučaj kada za tu uslugu nisu definisani tehnički zahtevi već ih treba obezbediti kroz razvoj. Sistem kvaliteta usluge se tome prilagođava.

Sve usluge VJ ugovara sa odabranim izvršiocima i nadležnostima po nivoima komandovanja.
U odnosu na modele usluga mogu se definisati modeli obezbeđenja sistema kvaliteta ISO (JUS), standarda koje treba primenjivati pri ugovaranju ili realizaciji usluga. $U$ odnosu na ISO standarde i modele može se preporučiti:

- kod modela korišćenja usluga koje se obavljaju za tržište, kvalitet usluga treba ugovarati po JUS-ISO 9000 (kao minimum) ili po JUS-ISO 9004, uz ugovaranje pojedinih elemenata sistema kvaliteta;

- kod modela koriśćenja usluga prilagođenih potrebama VJ, sistem kvaliteta treba ugovarati po standardu JUS-ISO 9004 (samo pojedinih elemenata), kao minimum ili 9004-2 kao optimalan zahtev;

- kod modela usluga koje se realizuju po specifičnim vojnim tehničkim zahtevima, sistem kvaliteta treba ugovarati po standardu JUS-ISO 9004-2;

- kod modela usluga koji se odnosi na osvajanje usluge može se preporučiti ugovaranje sistema kvaliteta prema standardu JUS-ISO 9001.

Već je istaknuto da navedeni standardi daju uputstva ili razrađuju modele za obezbeđenje kvaliteta u različitim situacijama nabavke i vršenja usluga. Međutim, za obezbeđenje realizacije zahteva iz standarda nužno je raspolagati odgovarajućim propisima ili standardima (međunarodnim ili domaćim) kojima se pokrivaju navedeni zahtevi. Vojska Jugoslavije $u$ tom pogledu koristi međunarodne, ali u najvećem broju slučajeva i domaće standarde $\mathbf{i}$ propise.

U daljem tekstu izvršena je analiza standarda i propisa kojima je regulisano njihovo sprovođenje. Pri tome, analiza je sprovedena do nivoa tačaka i podtačaka zahteva-elemenata standarda za obezbeđenje kvaliteta sredstava i usluga. 
Sistemska regulativa VJ za obezbeđenje kvaliteta tehnickkih sredstava í usluga prema modelima sistema kvaliteta u ISO standardima

Jedinice i ustanove Vojske Jugoslavije mogu nabavljati sredstva naoružanja i vojne opreme, tehnička materijalna sredstva i koristiti usluge po različitim varijantama:

- sredstva NVO se razvijaju, proizvode $\mathrm{i}$ održavaju isključivo po zahtevima taktičkog i tehničkog nosioca na osnovu dokumenata i regulative koja je propisana za $\mathrm{VJ}$;

- sredstva NVO razvija i proizvodi proizvođač na osnovu taktičkih i tehničkih zahteva koje je sam postavio ili ih naknadno usaglasio sa taktičkim i tehničkim nosiocima;

- tehnička materijalna sredstva sa tzv. tržišta gotovih proizvoda se delimično, po zahtevima taktičkog i tehničkog nosioca, najnužnije usaglašavaju potrebama VJ;

- tehnička materijalna sredstva Vojska Jugoslavije nabavlja na tržištu gotovih proizvoda bez ikakvih dorada ili prilagođavanja;

- osvajanje usluge uz definisanje tehničkih zahteva za uslugu i za sistem kvaliteta izvršioca;

- za Vojsku Jugoslavije obavljaju se usluge uz tačno definisanje zadataka isporučioca usluga $\mathrm{i}$ njegovog osposobljavanja za tu vrstu usluge, uz posebno definisanje sistema kvaliteta;

- za Vojsku Jugoslavije obavljaju se usluge za koje je izvršilac prilagodio svoj sistem kvaliteta;
- za Vojsku Jugoslavije obavljaju se usluge po sistemu kvaliteta kako isporučilac te usluge obavlja i za druge korisnike.

Navedene varijante nabavke i usluga za potrebe Vojske Jugoslavije ugovaraju se sa isporučiocima (proizvođačima) sredstava ili usluga. Vodeći računa o sadržaju navedenih varijanti i modelima za obezbeđenje kvaliteta prema međunarodnoj standardizaciji, može se zaključiti da se kvalitet može ugovoriti načelno po sva tri navedena modela (kada se koriste međunarodni standardi ISO 9001, 9002 i 9003). Međutim, VJ vrši ugovaranje u zavisnosti od nivoa komandovanja i potreba i kada se radi o uputstvima za upravljanje kvalitetom za bilo koju organizaciju, proizvođača ili isporučioca usluga, prema ISO 9000 i 9004, odnosno ISO 9004-2.

$\mathrm{Na}$ osnovu mogućih varijanti nabavki i usluga za potrebe VJ i modela za obezbeđenje kvaliteta preporučenih ISO (JUS) standardima, potrebno je identifikovati zahteve prema navedenim standardima.

Navedeno je da se razlikuju modeli za nabavku tehničkih sredstava (naoružanja i vojne opreme) i modeli za usluge za potrebe jedinica $i$ ustanova Vojske Jugoslavije.

Zbog toga je, vodeći računa o izvršenoj analizi, izvršena posebna identifikacija zahteva za sistem kvaliteta nabavki (Prilog 1 pod A) i za sistem kvaliteta usluga (Prilog 1 pod B). 
$\sum_{\substack{n \\ 2}}^{n}$

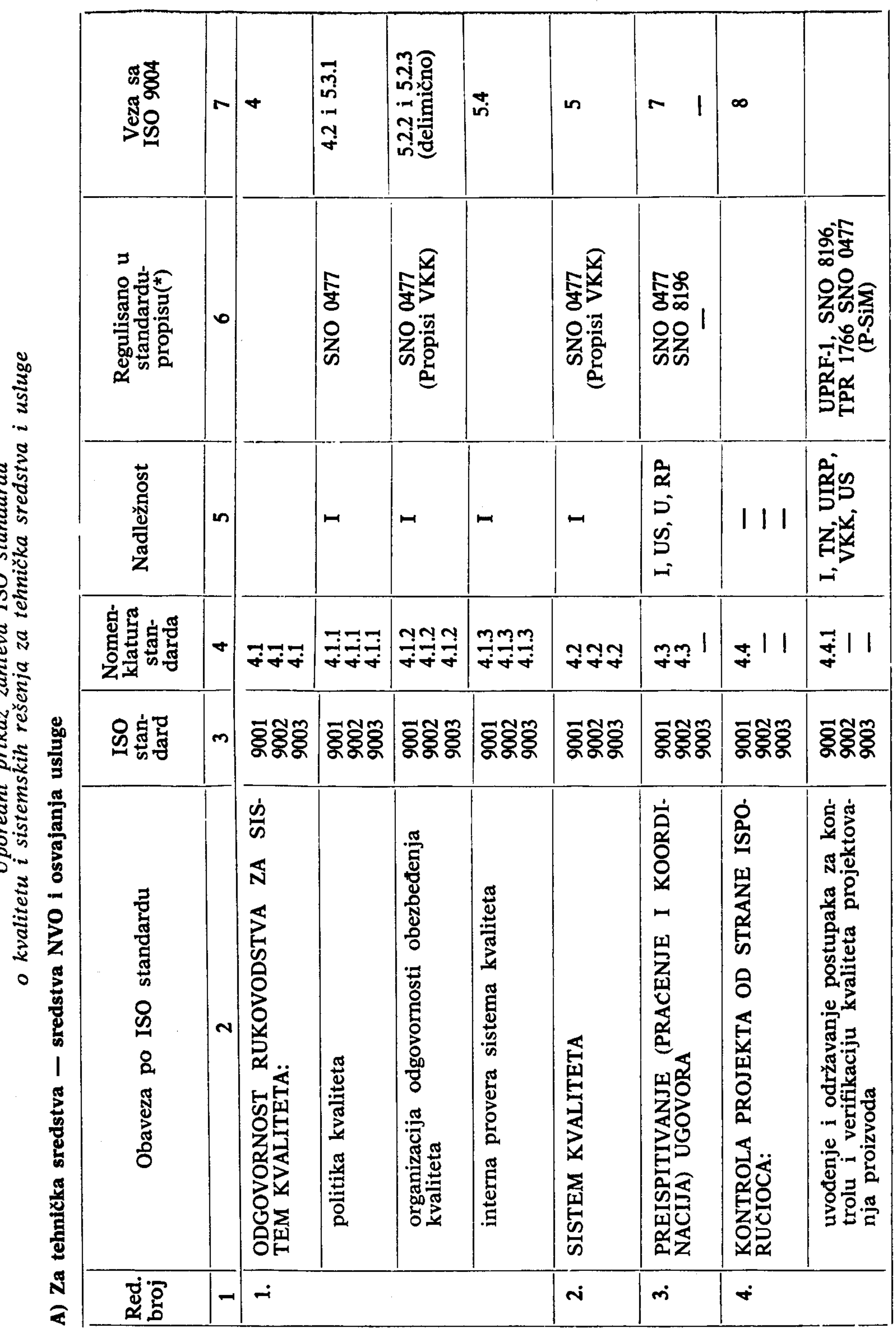




\begin{tabular}{|c|c|c|c|c|c|c|c|c|c|c|c|}
\hline r & $\begin{array}{c}\tilde{1} \\
\infty \\
-1\end{array}$ & $\begin{array}{l}n \\
\infty \\
\infty \\
\infty \\
\infty \\
\infty \\
-1 \\
\infty\end{array}$ & & & $\begin{array}{l}9 \\
\infty \\
\infty \\
\infty \\
\infty\end{array}$ & $I$ & & & $a$ & $\bar{a}$ & 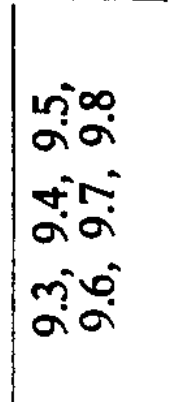 \\
\hline 0 & 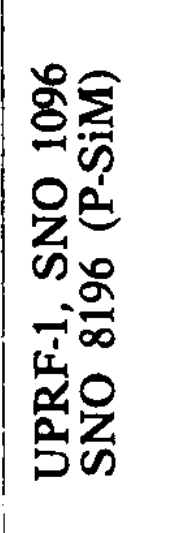 & 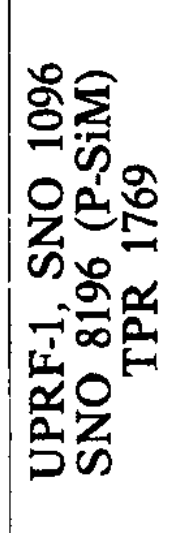 & 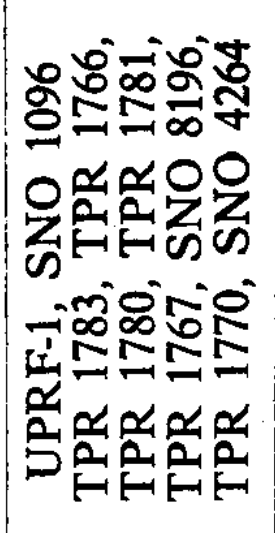 & 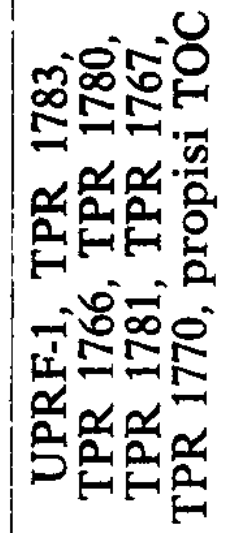 & $\mid \begin{array}{l}0 \\
0 \\
0 \\
0 \\
6 \\
0 \\
\frac{1}{2} \\
\frac{2}{2}\end{array}$ & & 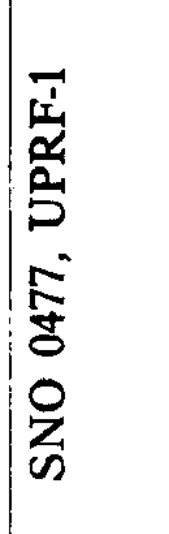 & 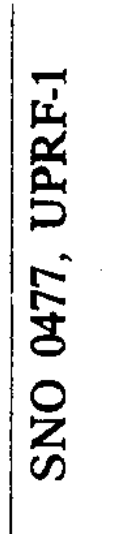 & & 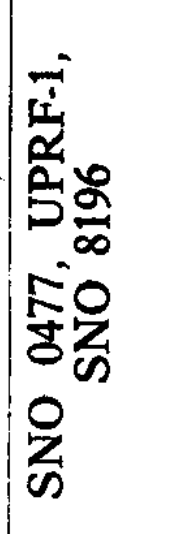 & 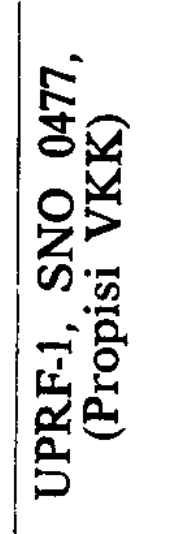 \\
\hline in & 总 & 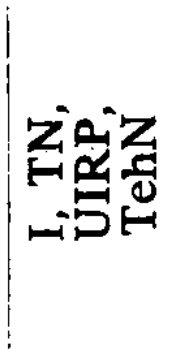 & 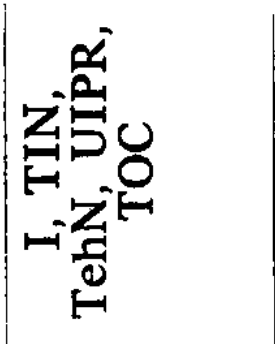 & 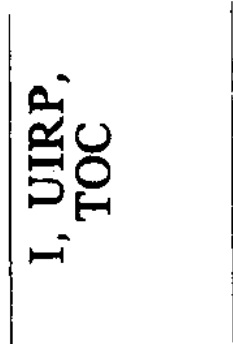 & $\begin{array}{l}\vec{a} \\
\underline{\sigma} \\
\sim \\
\sim\end{array}$ & & 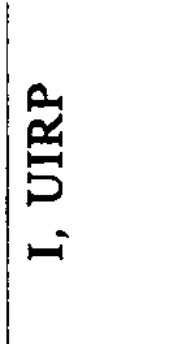 & 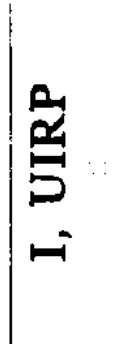 & & $\underset{n j}{a j}$ & $\frac{a j}{3}$ \\
\hline$\nabla$ & $\underset{+}{\stackrel{F}{*}} 11$ & $\underset{\stackrel{m}{+}}{+}|1|$ & $\underset{+}{+} 11$ & $\underset{\substack{n \\
+}}{+} 11$ & $\underset{+}{0} 11$ & भुषm & 㝒我| & ஸु̃ & | & 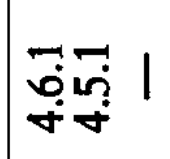 & $\mid$ \\
\hline$m$ & 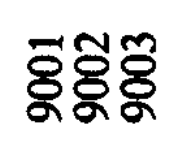 & ర్ర్రిశ్రిశ్ & 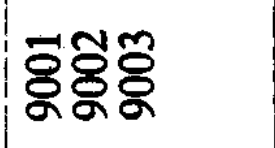 & 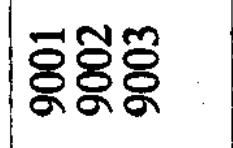 & 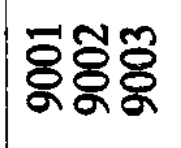 & 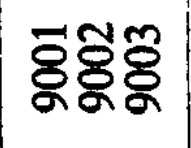 & ర్ర్రిర్రిం్రి & ర్ర్ర్ర్ & 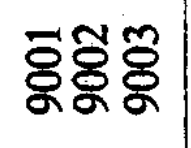 & ర్రీర్రిశ్ & 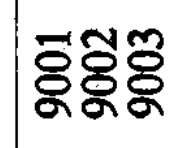 \\
\hline$N$ & 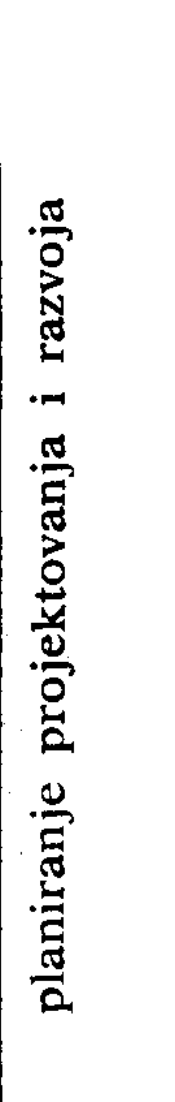 & 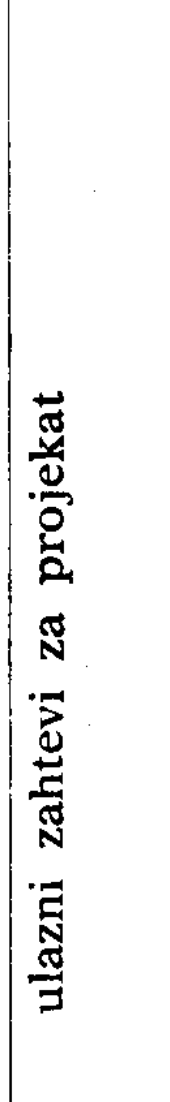 & 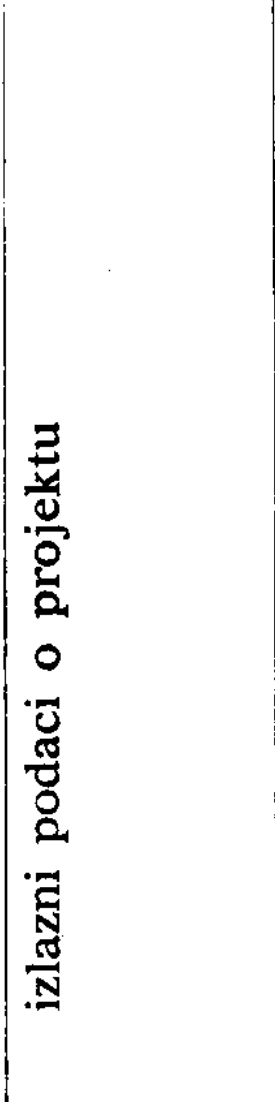 & 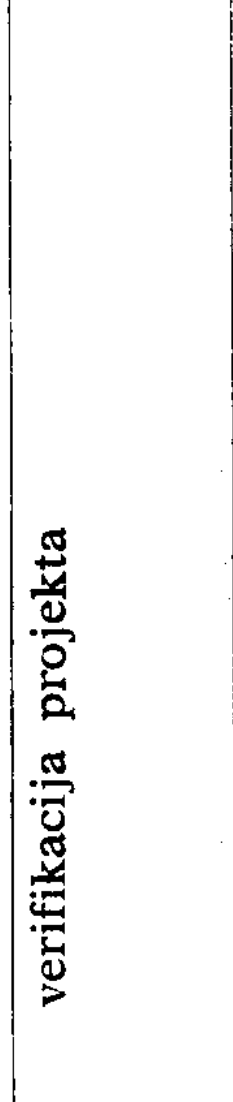 & 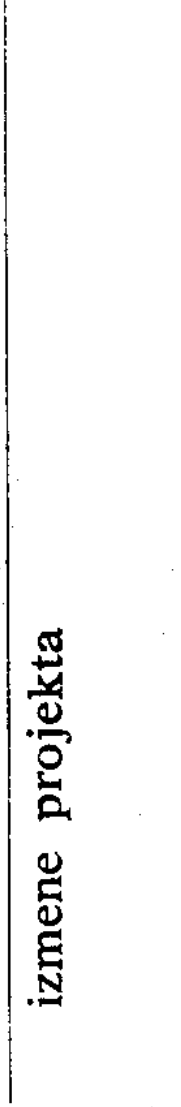 & 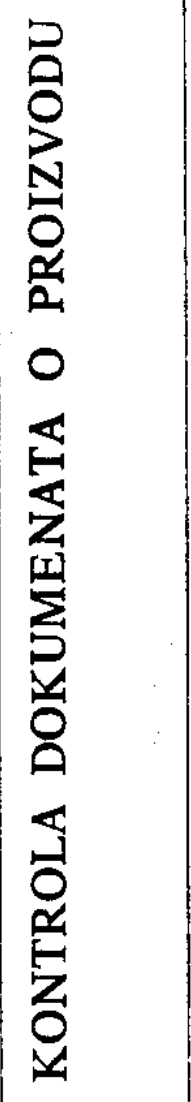 & 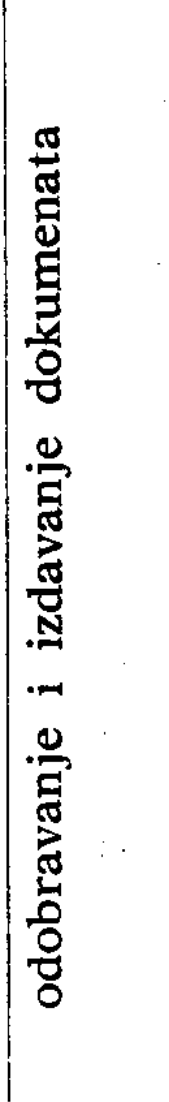 & 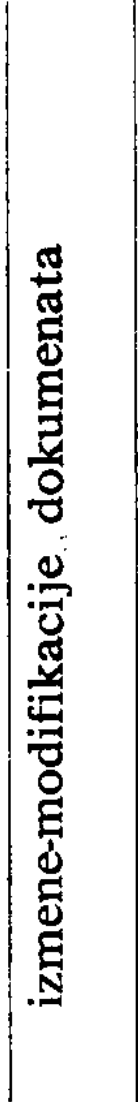 & 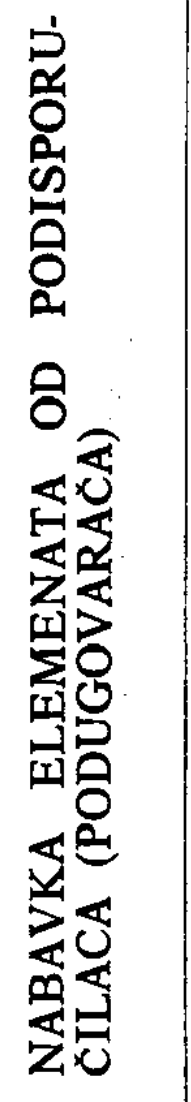 & 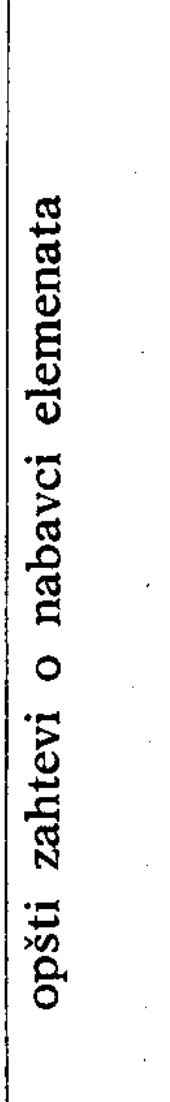 & 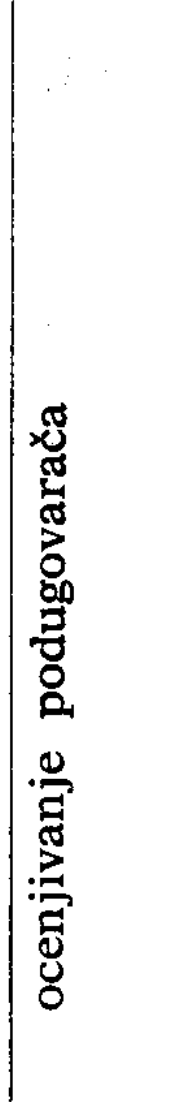 \\
\hline- & & & & $\because$ & & in & & & $\dot{0}^{\circ}$ & & \\
\hline
\end{tabular}




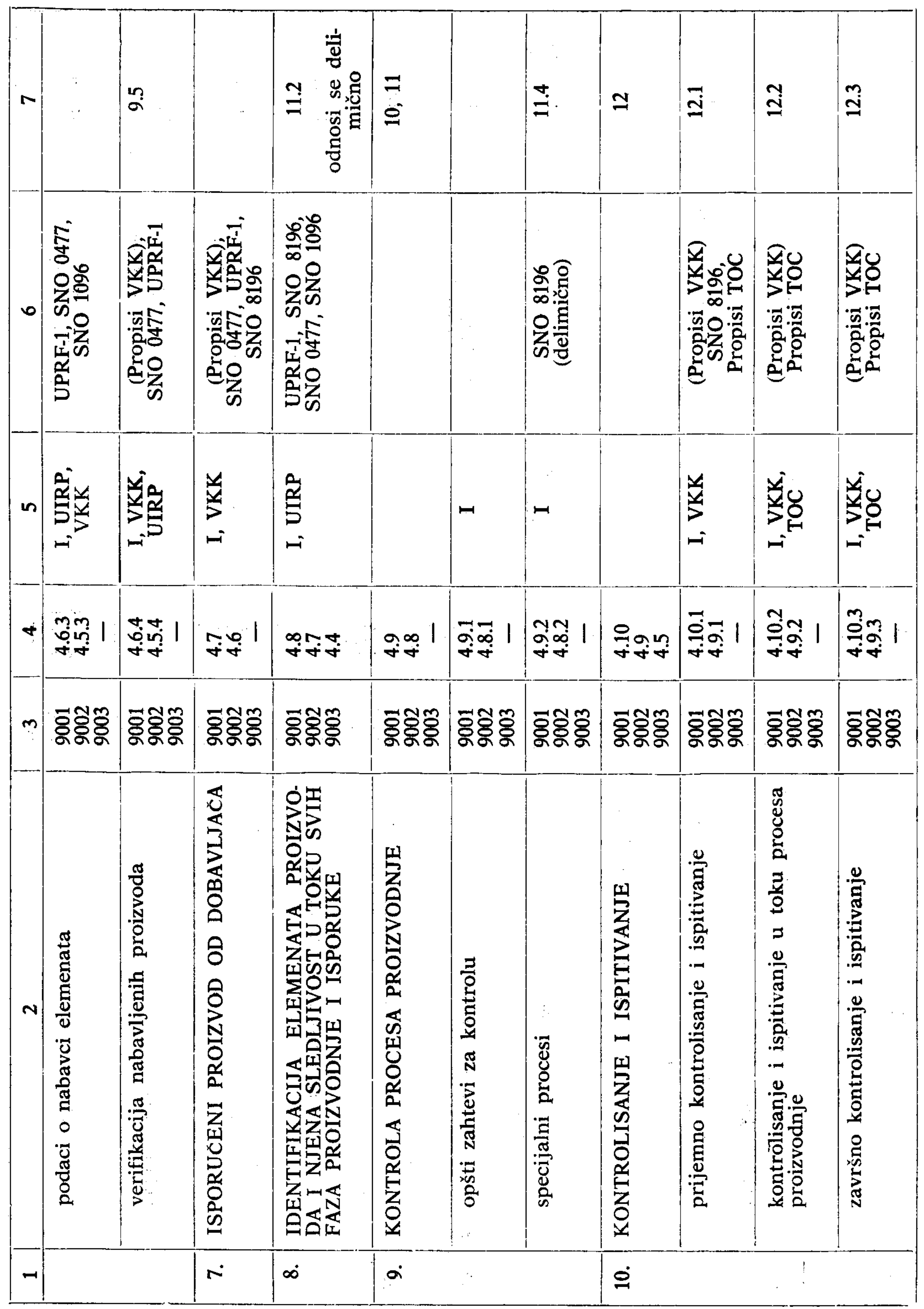




\begin{tabular}{|c|c|c|c|c|c|c|c|c|c|c|c|}
\hline$r$ & & $\begin{array}{l}m \\
\stackrel{m}{=}\end{array}$ & $\cong$ & 士 & 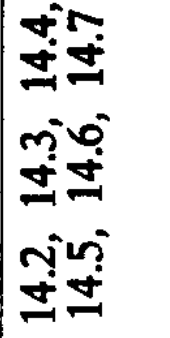 & 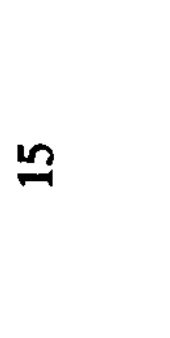 & $\stackrel{1}{1}$ & 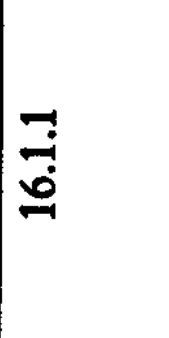 & $\underset{\hdashline}{1}$ & $\stackrel{7}{7}$ & 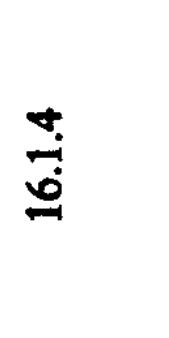 \\
\hline 0 & 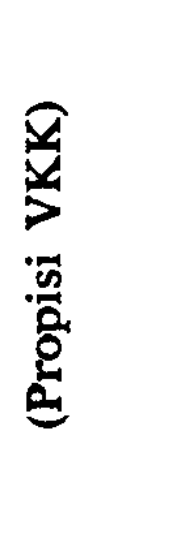 & 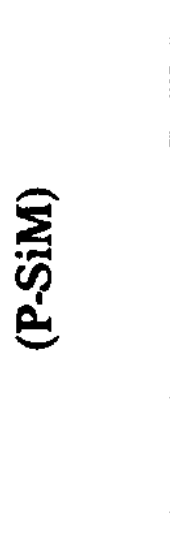 & 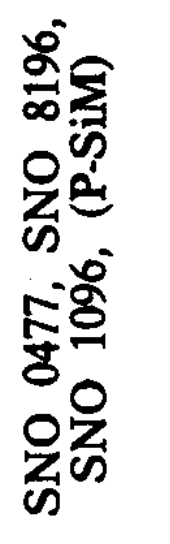 & & 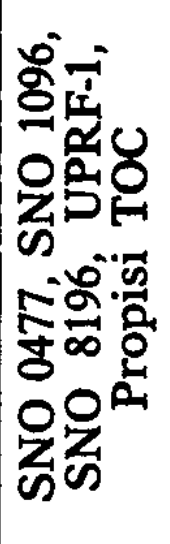 & 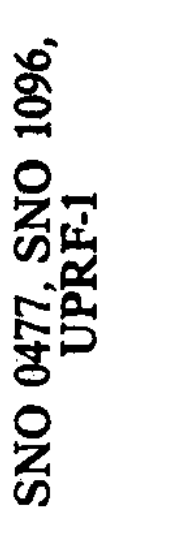 & & $\begin{array}{l}\frac{F}{\delta} \\
0 \\
\text { 岁 } \\
\text { s }\end{array}$ & 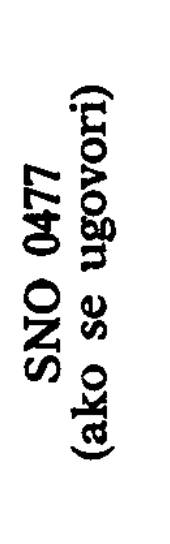 & 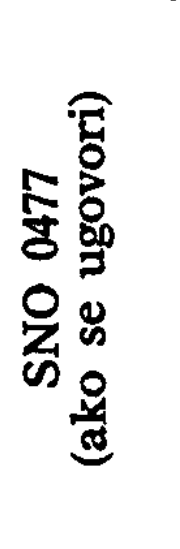 & 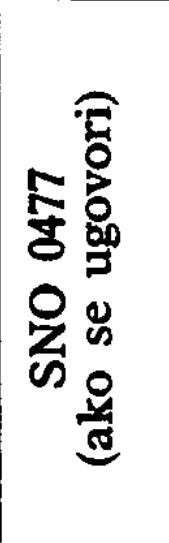 \\
\hline$n$ & - & $\frac{4}{5}$ & $\begin{array}{l}- \\
-\end{array}$ & & 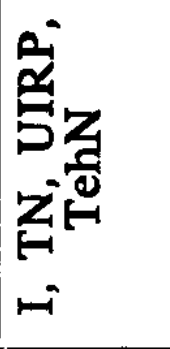 & $\omega$ & & $m$ & $m$ & $m$ & - \\
\hline+ & 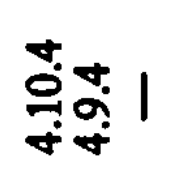 & 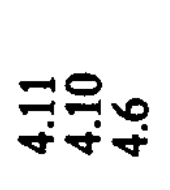 & $\underset{\forall}{Y} \underset{\forall}{ }$ & 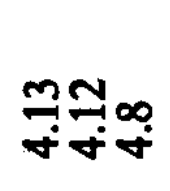 & 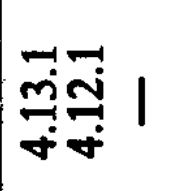 & $\underset{+}{+} \mid$ & 㹲: & 我离1 & 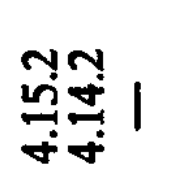 & 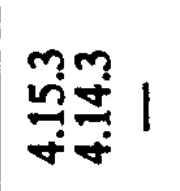 & 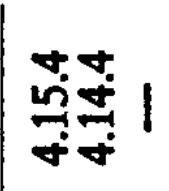 \\
\hline$m$ & ర్ర్ర్ర్రి & ర్ర్ర్ర్ర్ర్ర్ & ర్ర్ర్ర్ర్ర్ర్ & 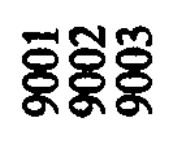 & 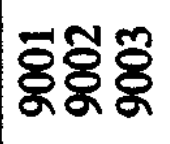 & 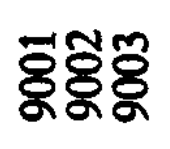 & ઠేઠ్ర్ఃి & ర్ర్ర్రీ్๊ర్ & ర్ర్ర్రీః్రి & ర్ర్ర్రీః్ & ర్ర్ర్ర్యి \\
\hline $\mathbf{N}$ & 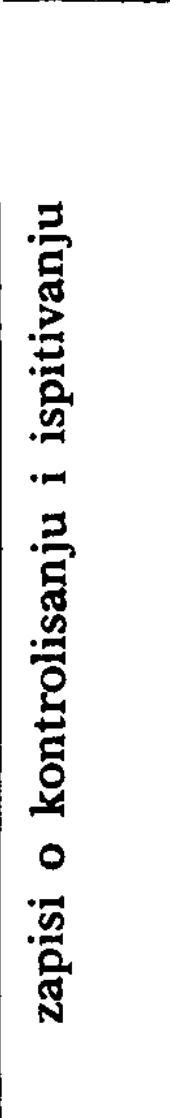 & 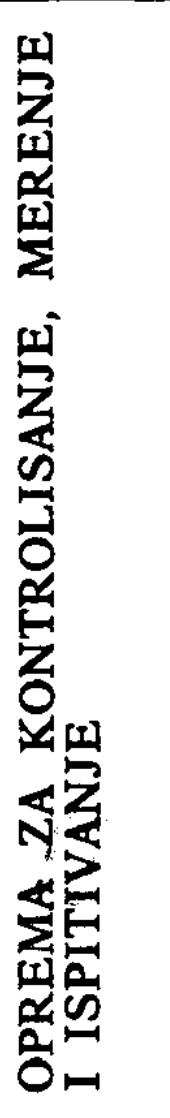 & 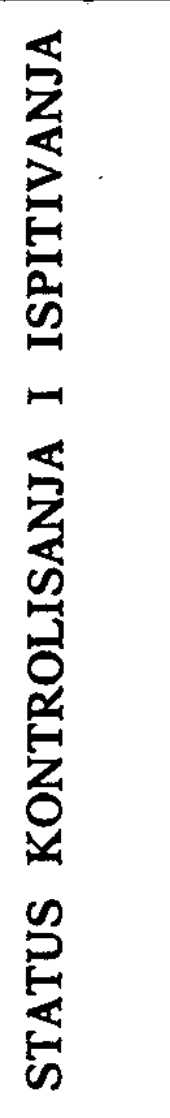 & 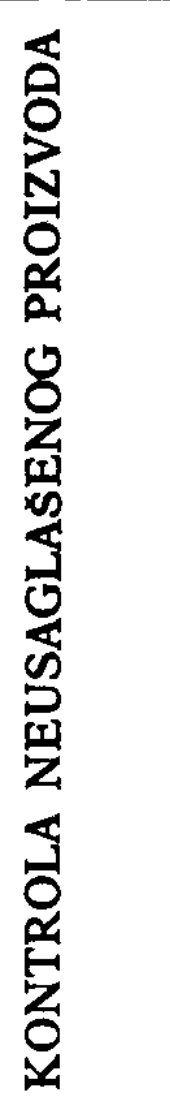 & 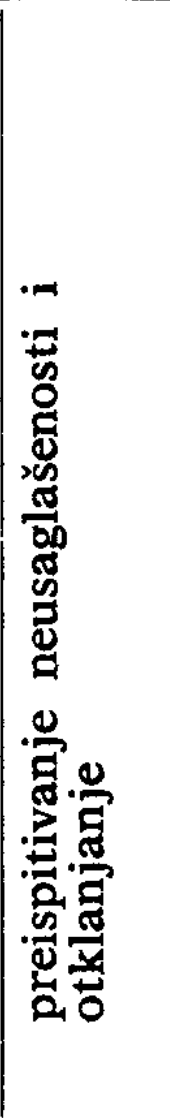 & 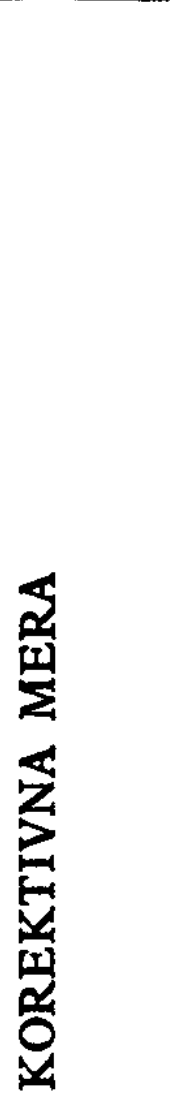 & 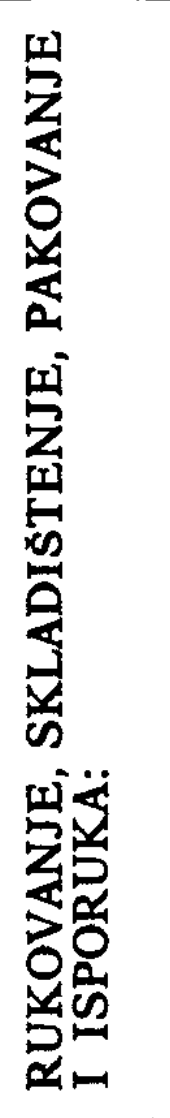 & 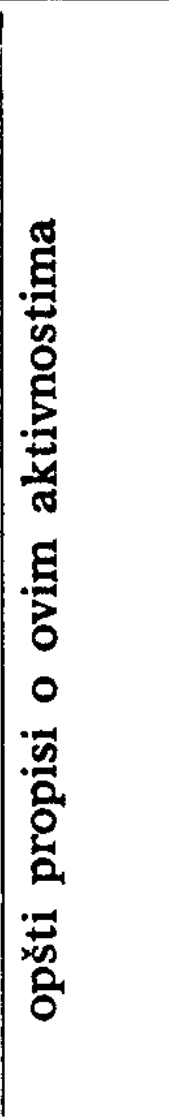 & 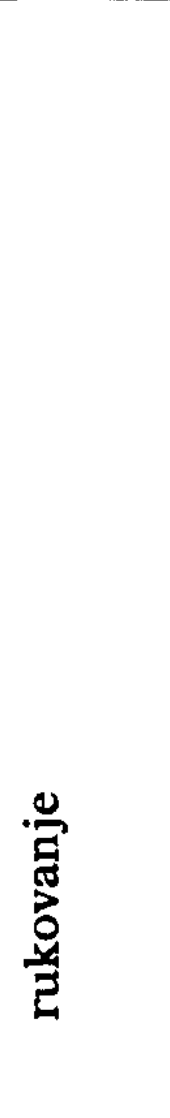 & 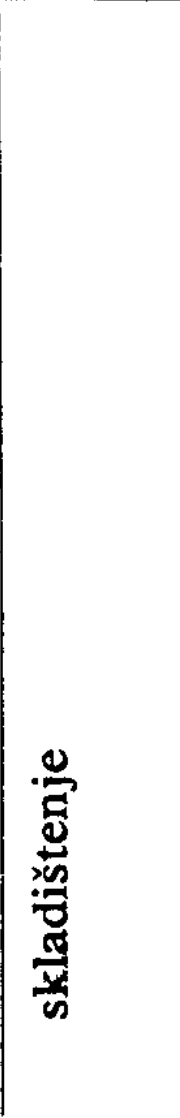 & 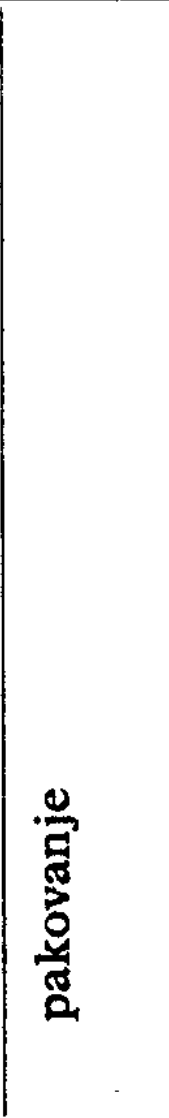 \\
\hline- & & $\doteq$ & $\stackrel{\check{I}}{ }$ & \multicolumn{2}{|l|}{ 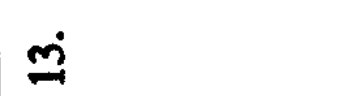 } & \pm & \multicolumn{5}{|l|}{$\stackrel{n}{n}$} \\
\hline
\end{tabular}




\begin{tabular}{|c|c|c|c|c|c|c|}
\hline$r$ & 茴 & $\begin{array}{l}\stackrel{m}{\Xi} \\
\stackrel{-}{\Xi} \\
= \\
\stackrel{-}{\Xi}\end{array}$ & ì & 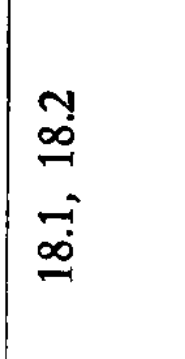 & ข้ & 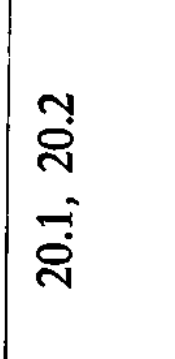 \\
\hline 0 & 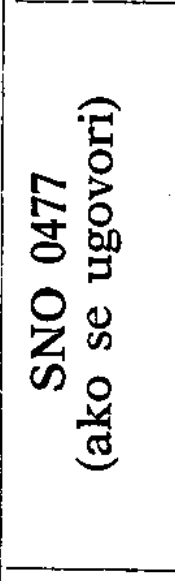 & 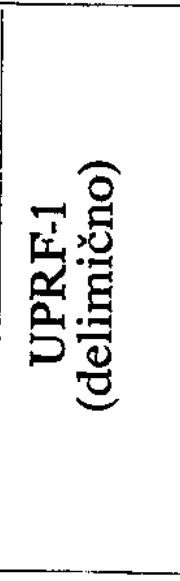 & 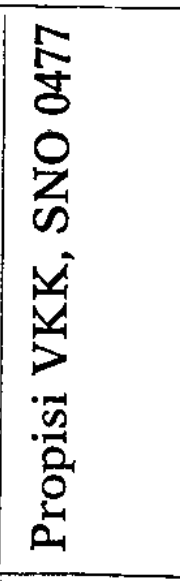 & 1 & 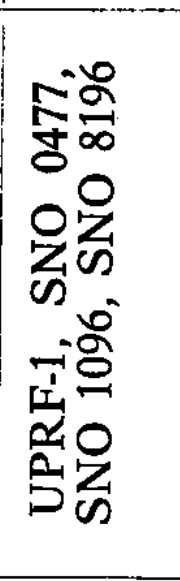 & 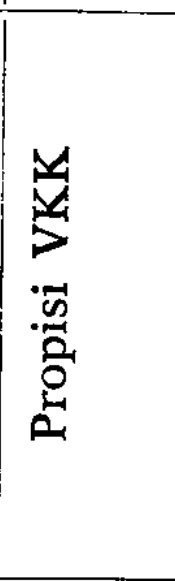 \\
\hline in & $m$ & $\mapsto$ & $\frac{y}{2}$ & $\mapsto$ & 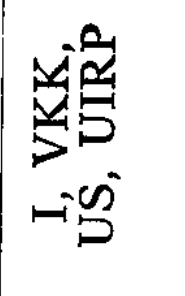 & $\begin{array}{l}3 \\
-i\end{array}$ \\
\hline+ & 能 & 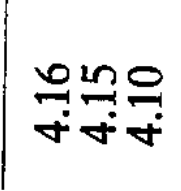 & 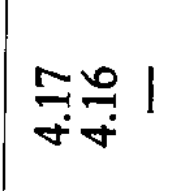 & $\stackrel{\infty}{\forall} \underset{\forall}{*}$ & $\underset{+}{\stackrel{9}{*}} \mid 1$ & 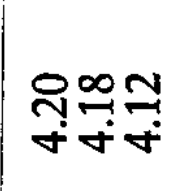 \\
\hline$m$ & 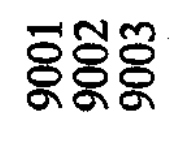 & 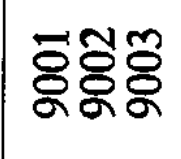 & 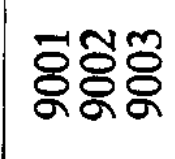 & 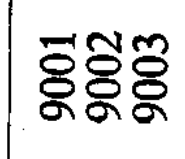 & 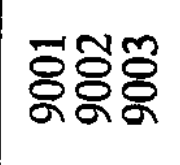 & 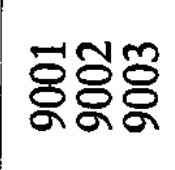 \\
\hline$N$ & 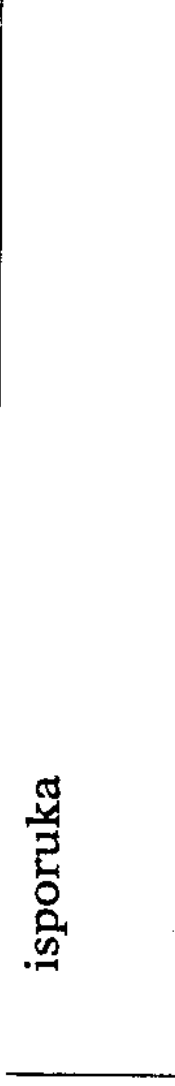 & 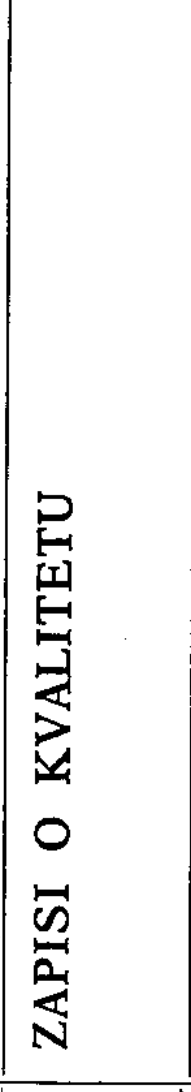 & 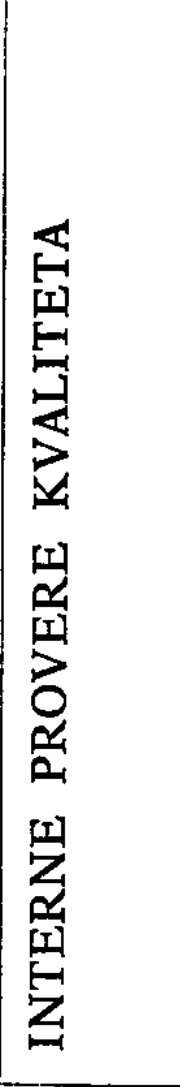 & 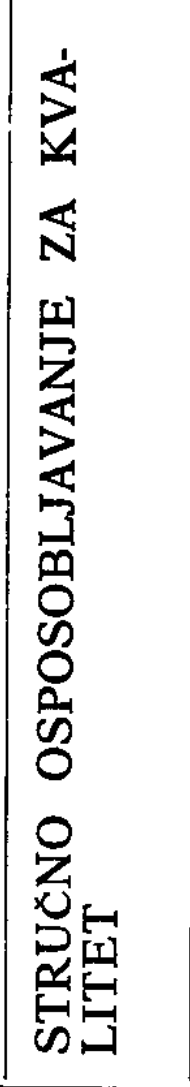 & 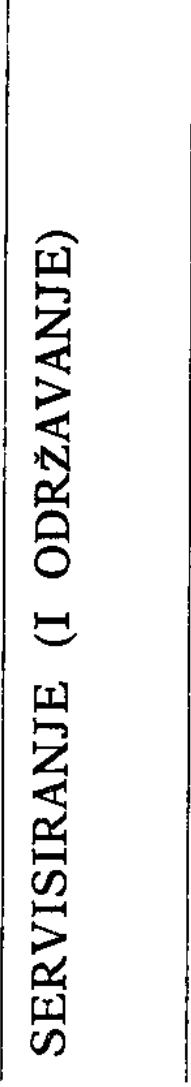 & 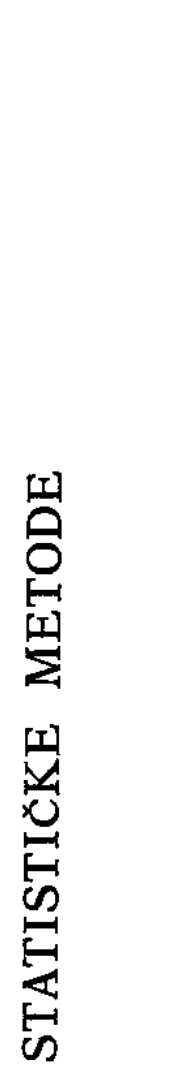 \\
\hline$\rightarrow$ & & $\stackrel{-1}{\circ}$ & $\stackrel{\dot{1}}{ }$ & $\stackrel{\infty}{=}$ & $\stackrel{\circ}{2}$ & ণ் \\
\hline
\end{tabular}




\begin{tabular}{|c|c|c|c|c|c|c|c|c|c|c|c|c|c|c|}
\hline & $N$ & & & & & 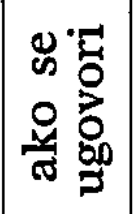 & 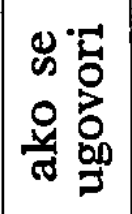 & 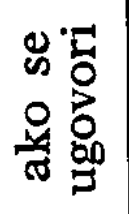 & & & & & & \\
\hline 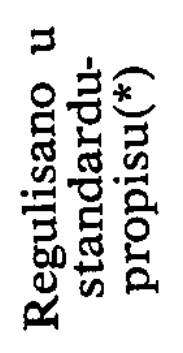 & 0 & & \begin{tabular}{l} 
T \\
苂 \\
0 \\
\multirow{2}{4}{}
\end{tabular} & 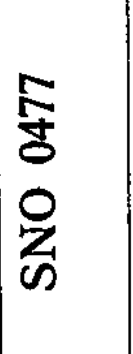 & & $\begin{array}{l}\frac{N}{J} \\
0 \\
0 \\
n \\
n\end{array}$ & 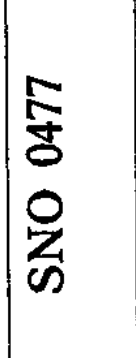 & 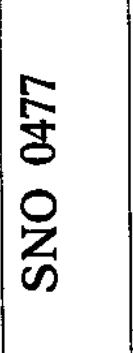 & 1 & 1 & 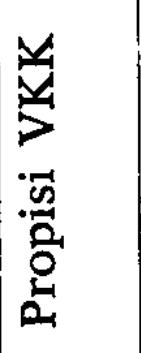 & & 1 & 1 \\
\hline 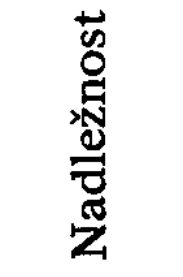 & in & & $\begin{array}{l}Z \\
Z \\
0 \\
0 \\
-1\end{array}$ & $\frac{a}{2}$ & & $\begin{array}{l}Z \\
\text { Z } \\
\text { d } \\
\sim-1 \\
-1\end{array}$ & $\begin{array}{l}Z \\
\frac{2}{0} \\
-1 \\
-1\end{array}$ & $\begin{array}{l}Z \\
\frac{1}{0} \\
-1 \\
-1\end{array}$ & $m$ & $\sqcap$ & $\frac{a}{2}$ & & 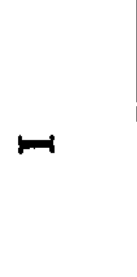 & 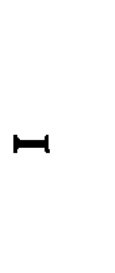 \\
\hline 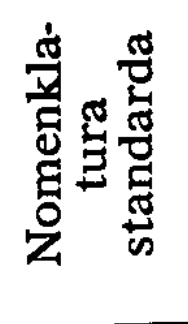 & + & $\nabla N$ & 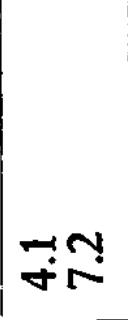 & 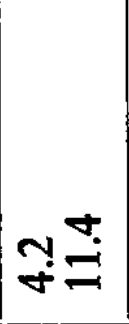 & men & मृ: & ํㅝ & ฟึ๊ & 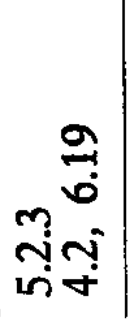 & 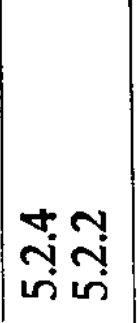 & $\begin{array}{l}\text { ñ } \\
\text { in }\end{array}$ & mั்ָ & $\stackrel{n}{m} \infty$ & 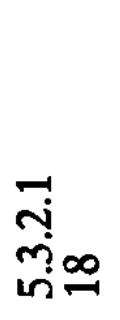 \\
\hline 命密总 & $m$ & 苍号 & 氐䓃 & 旁导 & 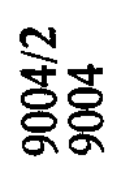 & 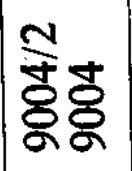 & 塞宫 & 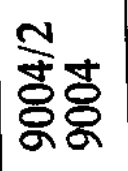 & 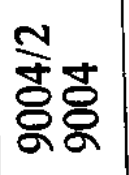 & 旁导 & 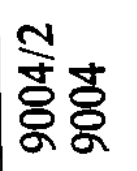 & 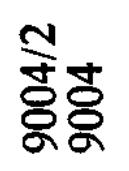 & 览灾 & 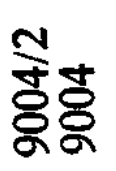 \\
\hline 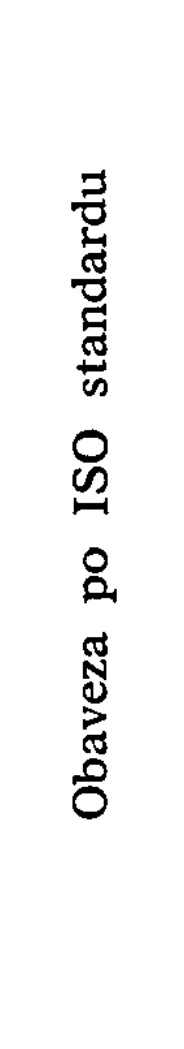 & $N$ & 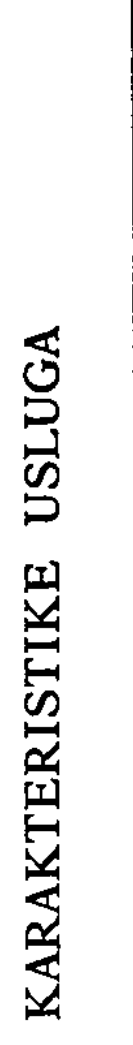 & 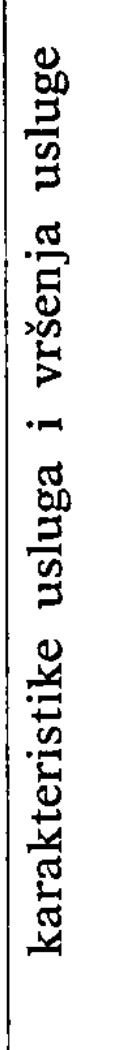 & 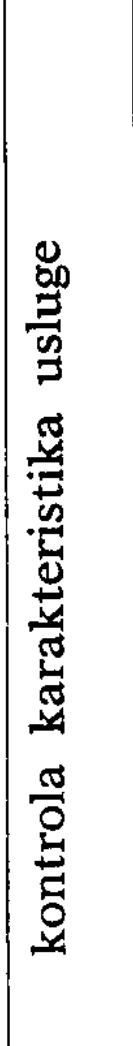 & 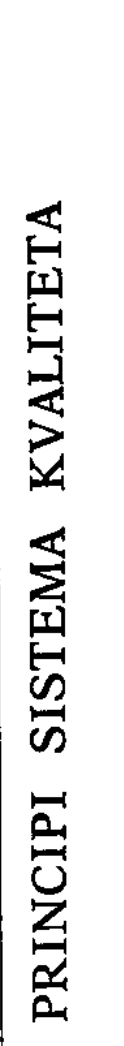 & 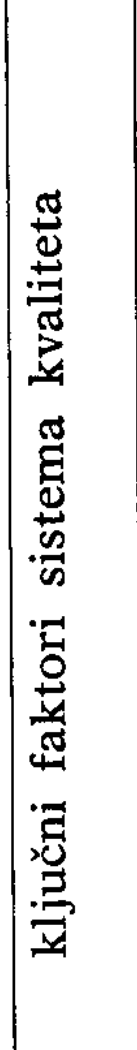 & 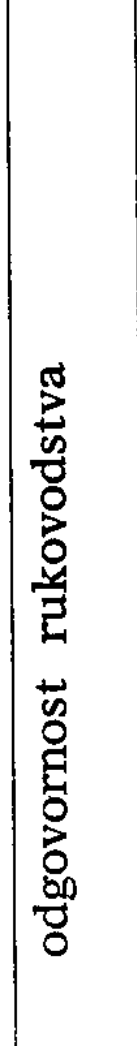 & 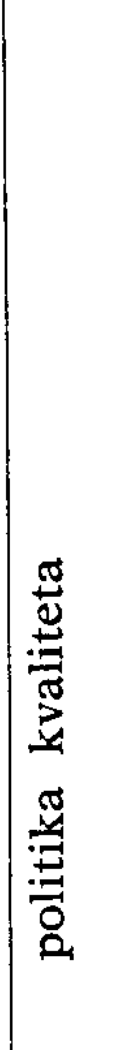 & 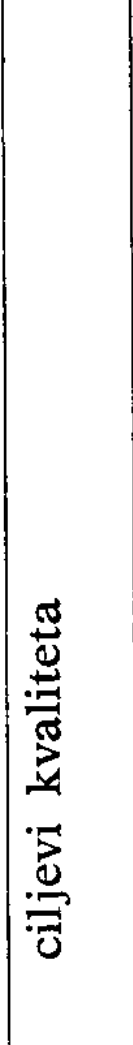 & 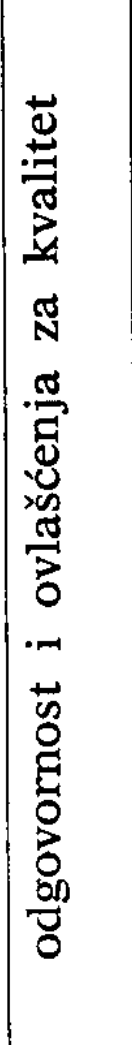 & 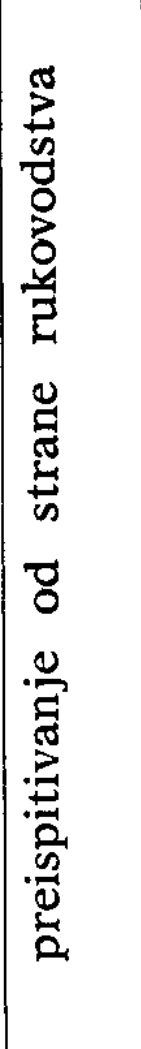 & 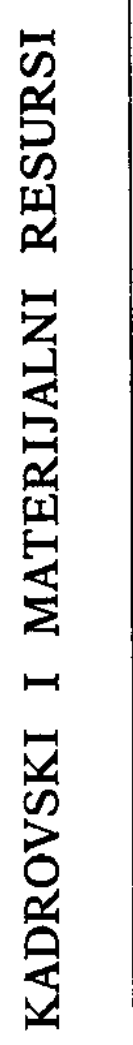 & 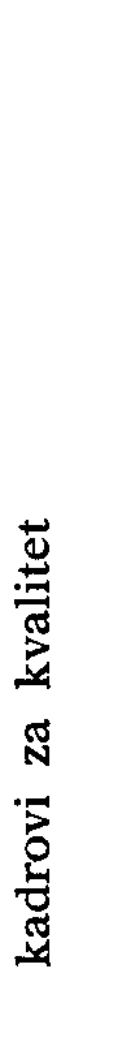 & 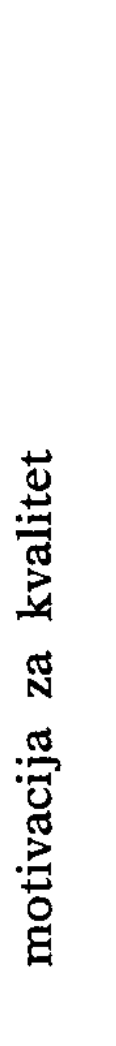 \\
\hline 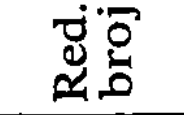 & -1 & \multicolumn{3}{|l|}{$-\dot{ }$} & \multicolumn{7}{|l|}{ i } & \multicolumn{3}{|l|}{$\dot{m}$} \\
\hline
\end{tabular}




\begin{tabular}{|c|c|c|c|c|c|c|c|c|c|c|c|c|c|c|c|}
\hline$N$ & & & 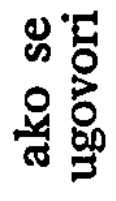 & & & & & 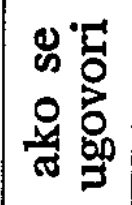 & & & & & & & \\
\hline 0 & 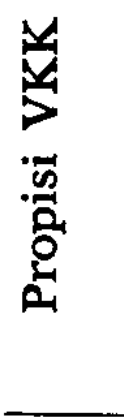 & 1 & $\begin{array}{l}\frac{5}{8} \\
0 \\
0 \\
Z\end{array}$ & & 1 & 1 & 1 & 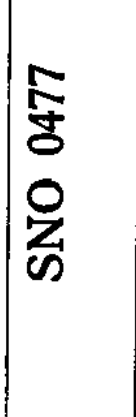 & 1 & 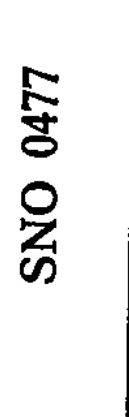 & 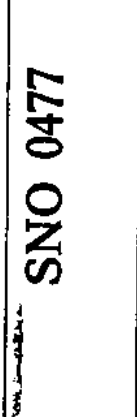 & & 1 & & 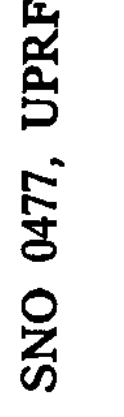 \\
\hline in & $\underset{n}{2}$ & $\begin{array}{l}\text { Z } \\
\frac{1}{0} \\
-1 \\
-1\end{array}$ & $\begin{array}{l}Z \\
\frac{1}{0} \\
-1 \\
-1\end{array}$ & & 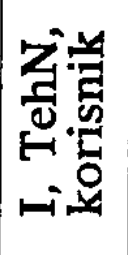 & $\frac{a}{2}$ & $\overbrace{-i}^{a}$ & $\sum_{n}^{2}$ & $\stackrel{2}{2}$ & ル. & 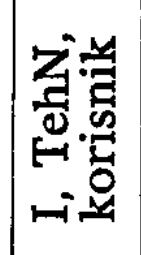 & & & $\mapsto$ & $\begin{array}{l}\text { Z } \\
\text { d } \\
\text { d } \\
-i\end{array}$ \\
\hline$\nabla$ & ֶָָ & $\begin{array}{l}m \\
\tilde{m} \\
m \\
m\end{array}$ & mid & 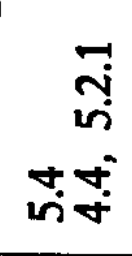 & $\underset{y}{y}$ & 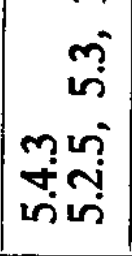 & 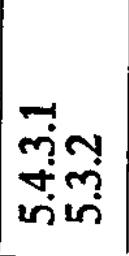 & 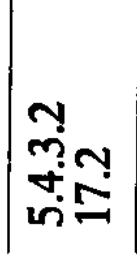 & ர் & ñm & กี่ & bin & G' & $\underset{10}{9}$ & 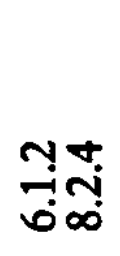 \\
\hline$m$ & 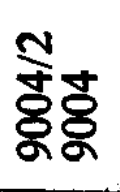 & 芦莟 & 芦志 & 旁志 & 芦灾 & 旁灾 & 芒灾 & 话志 & 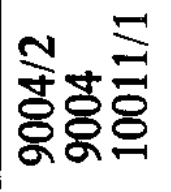 & 苍苂 & 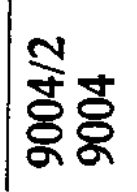 & 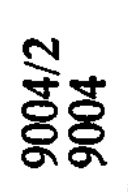 & 恣灾 & 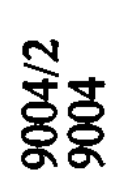 & 苍灾 \\
\hline$N$ & 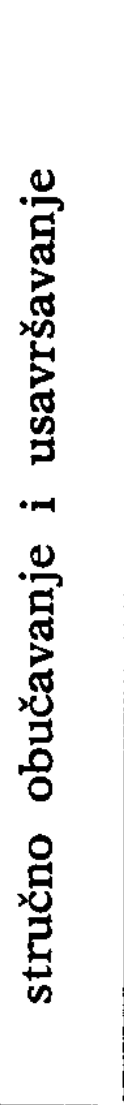 & 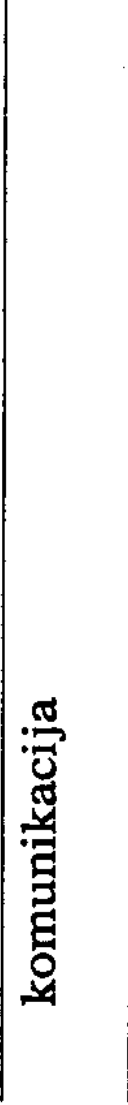 & 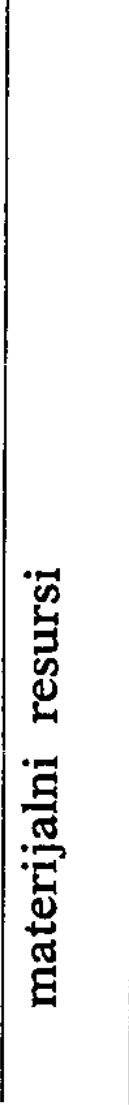 & 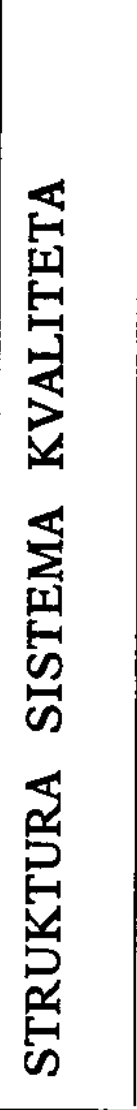 & 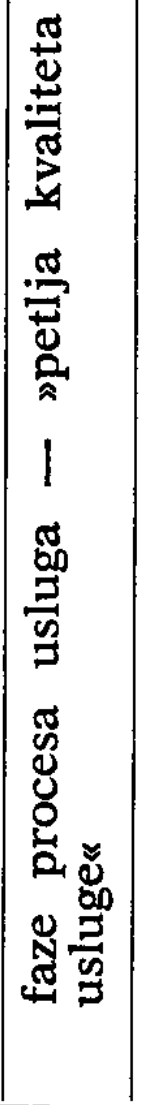 & 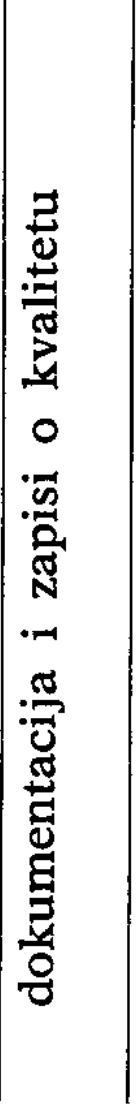 & 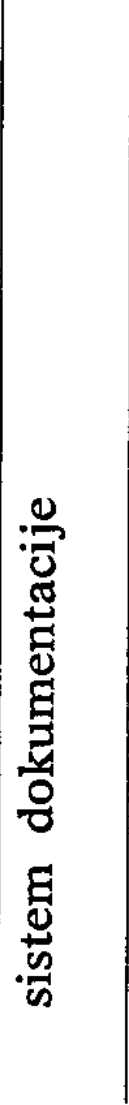 & 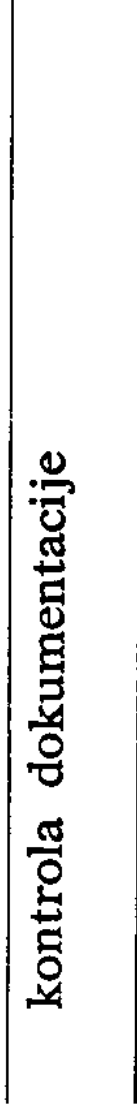 & 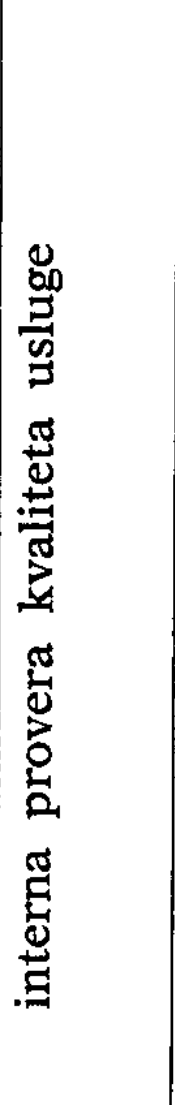 & 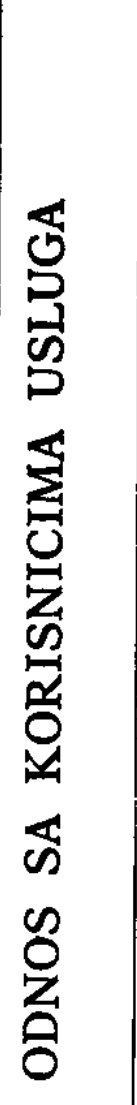 & 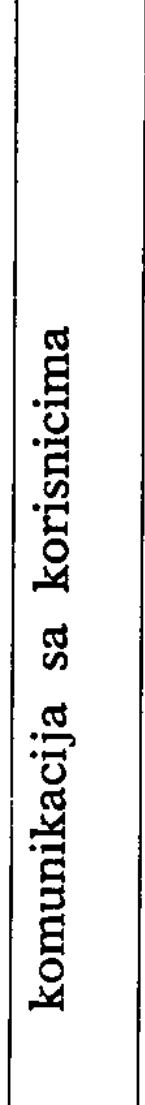 & 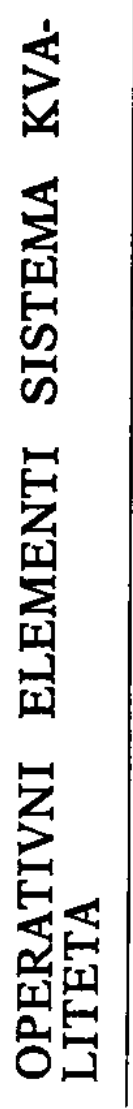 & 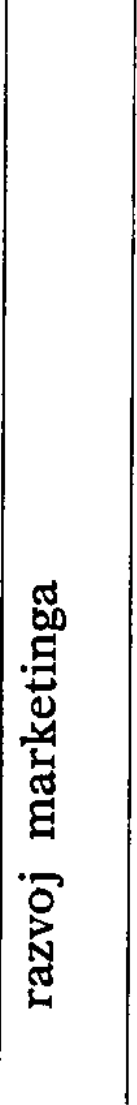 & 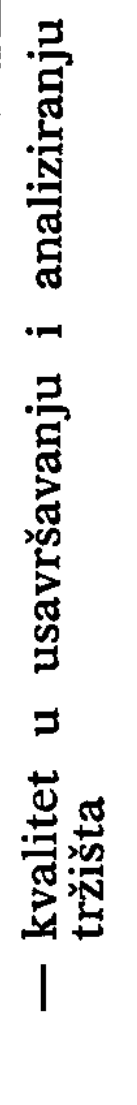 & 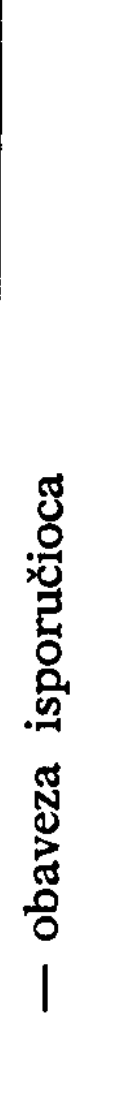 \\
\hline- & & & & \multicolumn{6}{|l|}{$\dot{\nabla}$} & \multicolumn{2}{|l|}{ ம் } & \multicolumn{4}{|l|}{$0^{\circ}$} \\
\hline
\end{tabular}




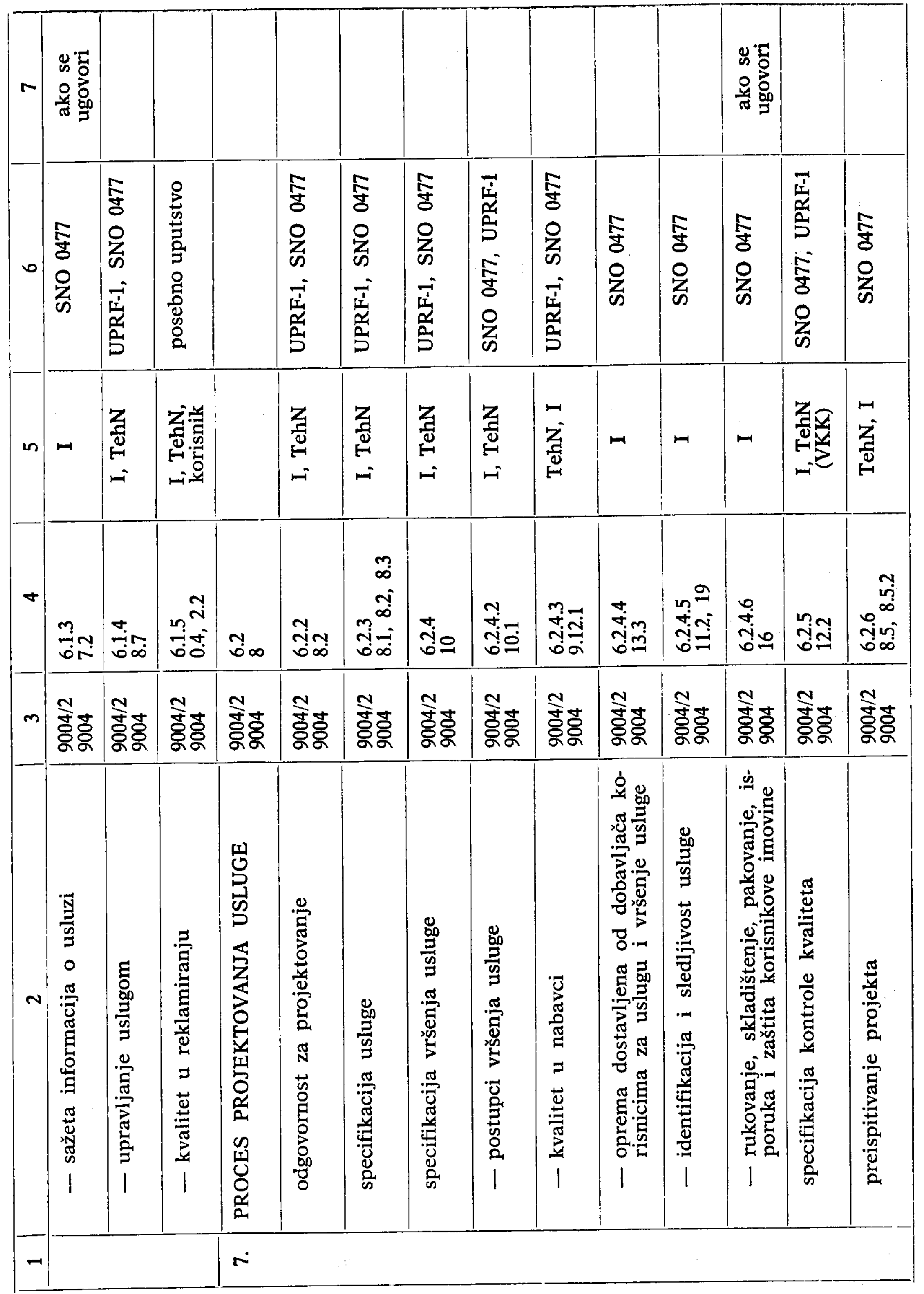




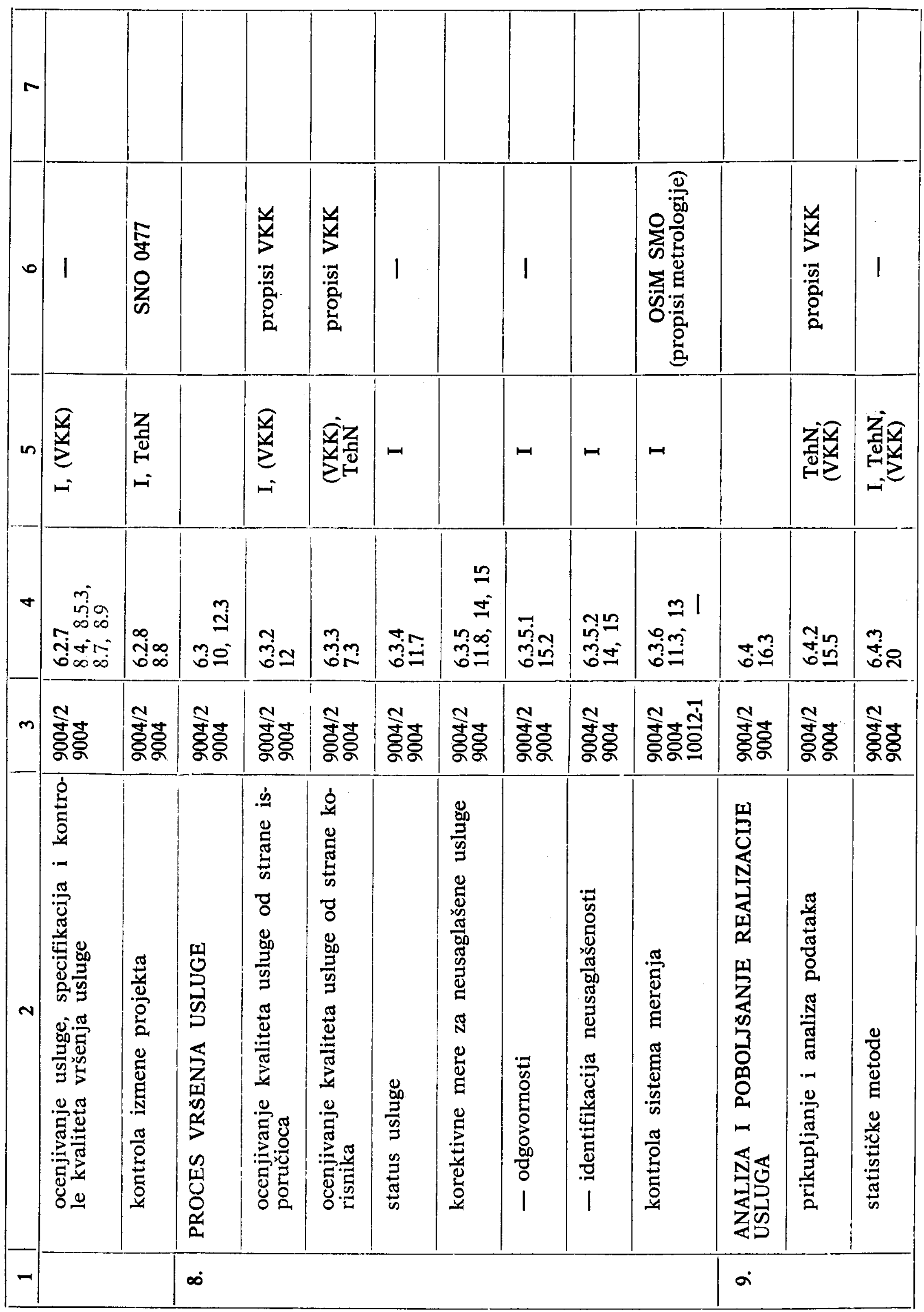




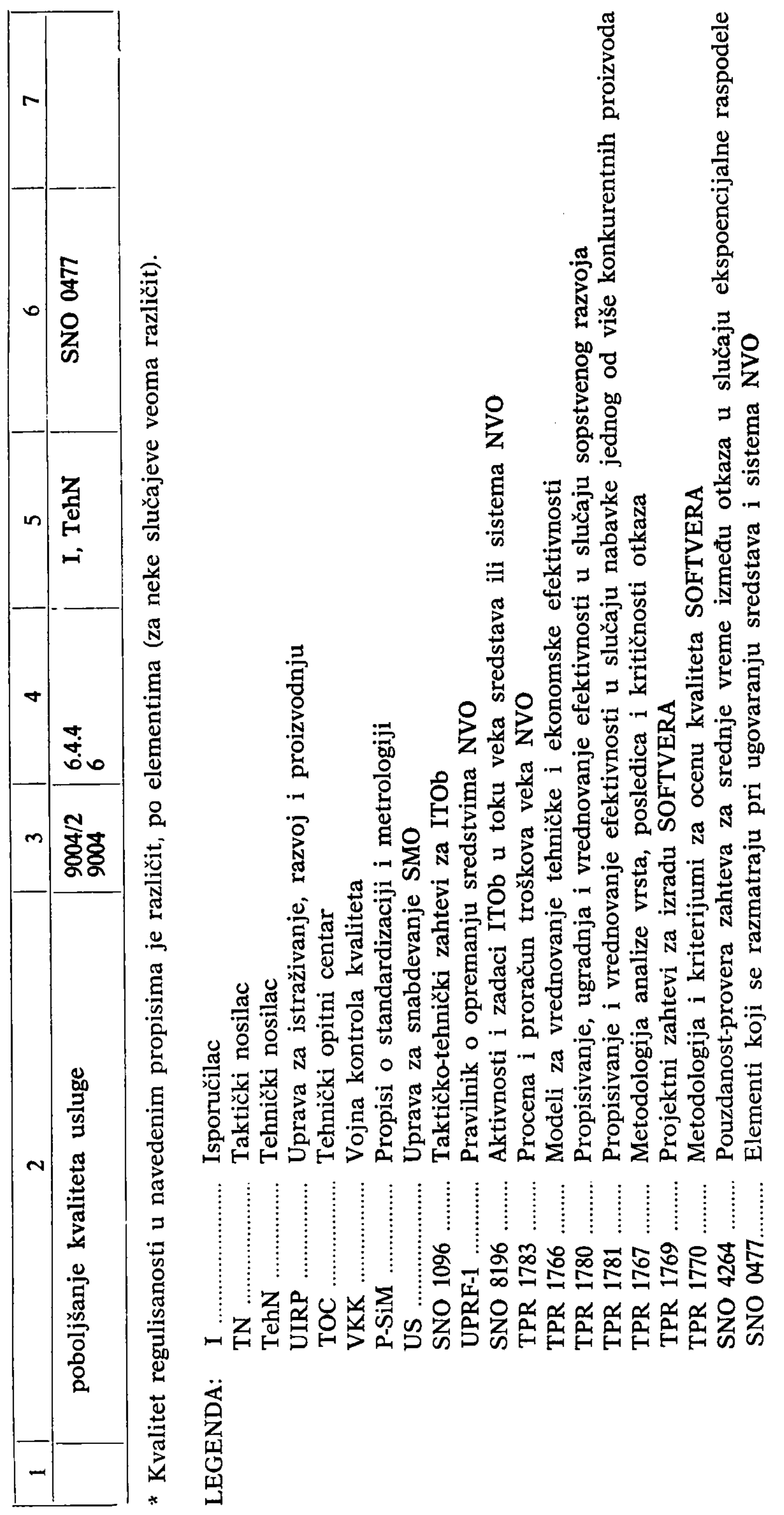


U oba slučaja je za svaku značajniju obavezu prema sistemu kvaliteta određen nadležni nosilac (kolona 5) i pridodat propis ili standard kojim VJ podržava (obezbeđuje) realizaciju navedenog zahteva sistema kvaliteta (kolona 6).

Radi preglednijeg upoređivanja elemenata sistema nabavki po tačkama i podtačkama, i njihove regulisanosti standardima i propisima za VJ, dat je Prilog 2. Pri razmatranju tog priloga nužno je uzeti u obzir napomene koje su uz njega date. Uz to, u velikim poslovnim sistemima, pa i u VJ, obaveze koje se odnose na nabavku, razvoj, proizvodnju, eksploataciju i održavanje tehničkih sredstava tačno su određene.

Taktički nosilac je zadužen za propisivanje tehničko-eksploatacionih karakteristika sredstava, kao i za njihovu eksploataciju. Tehnički nosilac se stara o postavljanju elemenata Integralnog tehničkog obezbeđenja i održava tehnička sredstva kroz svoj poseban sistem. Isporučilac sredstava, odnosno razvojni organi, ugrađuju sve zahteve taktičkog i tehničkog nosioca u sredstvo koje se razvija. Pri tome, definiše se i sistem kvaliteta, kako je prethodno već navedeno.

Radi jednoobraznosti postavljanja, ugradnje, ispitivanja i verifikacije svih zahteva, izrađuju se standardi i (ili) propisi. Pri tome, moguće je propisati i korišćenje međunarodnih standarda po pojedinim elementima, odnosno karakteristikama sredstava i sistema u koji ulaze, eksploatišu se i održavaju u toku njihovog životnog veka.

Slične nadležnosti, kada se radi o tehničkim sredstvima, određuju se i za usluge. Takođe, i kod njih je određen taktički nosilac, ali pošto se radi o tehničkim organima ta se obaveza pripisuje tehničkom nosiocu. Obaveze i zadaci izvršioca su slični kao za isporučioca tehničkih sredstava.

Iz Priloga 1 i 2 i sadržaja pojedinih zahteva po ISO standardima (tač- ke i podtačke), može se uočiti da je isti zahtev regulisan sa više propisa ili standarda. Pri tome treba uočiti da neki zahtevi uopšte nisu pokriveni propisima $\mathrm{i}$ standardima, a ističe se $\mathrm{i}$ činjenica da kvalitet navedenih propisa i standarda nije najčešće takav da u celini dovoljno jasno i precizno reguliše obezbeđenje sistema kvaliteta tog elementa definisanog odgovarajućom tačkom ili podtačkom.

Ove činjenice ukazuju na to da je prerada i prilagođavanje izdatih propisa i standarda VJ u izvesnoj meri nužna, kao i potreba za posebnim propisivanjem da se pokrivanje pojedinih elemenata sistema kvaliteta mora vršiti ostalim međunarodnim standardima.

Za današnje vreme je značajno da sistem kvaliteta usluga skoro uopšte nije pokriven odgovarajućim propisima ili standardima. Ako se uzme u obzir da se veliki deo elemenata sistema kvaliteta i nabavke, a posebno usluga, reguliše samo kroz ugovor (SNO 0477), onda je potreba za izradom i prilagođavanjem domaće $\mathbf{i}$ inostrane regulative za sistem kvaliteta, veoma značajna.

Pošto se radi o minimalnim zahtevima koji se regulišu međunarodnim standardima, ukazuje se na to da svaka zemlja mora proširivati i prilagođavati međunarodne standarde svojim potrebama. Vojska, kao specifičan sistem, mora svoju metodologiju razvoja, proizvodnje, eksploatacije i održavanja tehničkih sredstava i usluga vezanih za tehnička sredstva, stalno da proširuje, prilagođava i usavršava. Taj stav je vrlo značajan i ukazuje na to da je metodologija Integralnog tehničkog obezbeđenja, koja je postavljena i stalno se usavršava i razvija, potrebna i nezamenljiva.

Treba napomenuti da se odgovarajući međunarodni (a sada i domaći) standardi odnose na bilo koje usluge, a pošto su u VJ određeni taktički i tehnički nosioci, te isporučioci i izvršioci usluga, izvršena analiza može da 
Rekapitulacija odnosa zahteva ISO standarda o kvalitetu sredstava NVO $i$ TMS $i$ sistemskih rešenja

\begin{tabular}{|c|c|c|c|c|c|}
\hline$=2$ & Obaveza po ISO standardu & & & & $\begin{array}{l}\text { Regulisano } \mathrm{u} \\
\text { standardu - }\end{array}$ \\
\hline 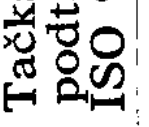 & & $\begin{array}{l}\text { ISO } \\
9001\end{array}$ & $\begin{array}{l}\text { ISO } \\
9002\end{array}$ & $\begin{array}{l}\text { ISO } \\
9003\end{array}$ & \\
\hline 1 & 2 & 3 & 4 & 5 & 6 \\
\hline 4. & Odgovornost rukovodstva & 4.1 & 4.1 & 4.1 & SNO 0477 (delimično) \\
\hline 5. & Principi sistema kvaliteta & 4.2 & 4.2 & 4.2 & SNO 0477 (delimično) \\
\hline 5.4 & $\begin{array}{l}\text { Proveravanje sistema kvaliteta } \\
\text { (interno) }\end{array}$ & 4.17 & 4.16 & - & $\begin{array}{l}\text { propisi VKK } \\
\text { SNO } 0477\end{array}$ \\
\hline 6. & $\begin{array}{l}\text { Ekonomika-razmatranje troškova kva- } \\
\text { liteta }\end{array}$ & - & - & - & - \\
\hline 7. & $\begin{array}{l}\text { Kvalitet u marketingu (preispitivanje } \\
\text { ugovora) }\end{array}$ & 4.3 & 4.3 & - & $\begin{array}{l}\text { SNO } 0477 \\
\text { SNO } 8196\end{array}$ \\
\hline 8. & $\begin{array}{l}\text { Kvalitet u specifikaciji i projektu (kon- } \\
\text { trola projekta) }\end{array}$ & 4.4 & - & - & $\begin{array}{l}\text { UPRF-1, SNO } 8196, \\
\text { SNO 0477, SNO } 1096 \mathrm{i} \\
\text { TPR, SNO } 4264\end{array}$ \\
\hline 9. & Kvalitet $\mathrm{u}$ nabavci (nabavka) & 4.6 & - & - & $\begin{array}{l}\text { SNO 0477, UPRF-1, } \\
\text { SNO } 8196\end{array}$ \\
\hline 10. & $\begin{array}{l}\text { Kvalitet u proizvodnji (kontrola pro- } \\
\text { cesa) }\end{array}$ & 4.9 & 4.8 & - & propisi VKK \\
\hline 11. & Kontrola proizvodnje & 4.9 & 4.8 & - & $\begin{array}{l}\text { propisi VKK } \\
\text { SNO } 8196\end{array}$ \\
\hline 11.2 & $\begin{array}{l}\text { Kontrola materijala i sledljivost (iden- } \\
\text { tifikacija i sledljivost proizvoda) }\end{array}$ & 4.8 & 4.7 & 4.4 & $\begin{array}{l}\text { UPRF-1, SNO } 8196 \\
\text { SNO 0477, SNO } 1096\end{array}$ \\
\hline 11.7 & $\begin{array}{l}\text { Kontrola statusa verifikacije (status } \\
\text { kontrolisanja i ispitivanja) }\end{array}$ & 4.12 & 4.11 & 4.7 & $\begin{array}{l}\text { SNO 0477, SNO } 8196, \\
\text { SNO 1096, } \\
\text { propisi SiM }\end{array}$ \\
\hline 12. & $\begin{array}{l}\text { Verifikacija proizvoda (kontrolisanje i } \\
\text { ispitivanje) }\end{array}$ & 4.10 & 4.9 & 4.5 & $\begin{array}{l}\text { propisi VKK } \\
\text { propisi TOC }\end{array}$ \\
\hline 13. & $\begin{array}{l}\text { Kontrola merne } \mathrm{i} \text { ispitne opreme (op- } \\
\text { reme za kontrolisanje, merenje } \mathrm{i} \text { ispi- } \\
\text { tivanje) }\end{array}$ & 4.11 & 4.10 & 4.6 & propisi SiM \\
\hline 14. & $\begin{array}{l}\text { Neusaglašenost (kontrola neusaglašeno- } \\
\text { sti proizvoda) }\end{array}$ & 4.13 & 4.12 & 4.8 & $\begin{array}{l}\text { SNO 0477, SNO 1096, } \\
\text { SNO 8196, UPRF-1 }\end{array}$ \\
\hline 15. & Korektivna mera & 4.14 & 4.13 & - & $\begin{array}{l}\text { SNO 0477, SNO } 1096 \text {, } \\
\text { UPRF-1 }\end{array}$ \\
\hline 16. & $\begin{array}{l}\text { Rukovanje i funkcije posle proizvod- } \\
\text { nje (rukovanje, skladištenje, pakovanje } \\
\text { i isporuka) }\end{array}$ & 4.15 & 4.14 & 4.9 & SNO 0477 \\
\hline 16.2 & Servisiranje posle prodaje & 4.19 & - & - & $\begin{array}{l}\text { UPRF-1, SNO } 0477, \\
\text { SNO } 1096, \text { SNO } 8196\end{array}$ \\
\hline 17. & $\begin{array}{l}\text { Dokumentacija i zapisi o kvalitetu (kon- } \\
\text { trola dokumenata) }\end{array}$ & 4.5 & 4.4 & 4.3 & SNO 0477, UPRF-1 \\
\hline
\end{tabular}




\begin{tabular}{|c|l|c|c|c|c|}
\hline 1 & \multicolumn{1}{|c|}{2} & 3 & 4 & 5 & 6 \\
\hline 17.3 & Zapisi o kvalitetu & 4.16 & 4.15 & 4.10 & UPRF-1 (delimično) \\
\hline 18. & Kadrovi (stručno osposobljavanje) & 4.18 & 4.17 & 4.11 & - \\
\hline 19. & $\begin{array}{l}\text { Bezbednost proizvoda i odgovornost za } \\
\text { proizvod }\end{array}$ & - & - & - & - \\
\hline 20. & $\begin{array}{l}\text { Korišćenje statističkih metoda (statis- } \\
\text { tičke metode) }\end{array}$ & 4.20 & 4.18 & 4.12 & propisi VKK \\
\hline- & Isporučeni proizvod od dobavljača & 4.7 & 4.6 & - & $\begin{array}{l}\text { SNO 0477, UPRF-1, } \\
\text { SNO 1096, SNO 8196 }\end{array}$ \\
\hline
\end{tabular}

NAPOMENE: 1. Zahtevi elemenata sistema kvaliteta po pojedinim standardima su identični, ali ne u svakom slučaju.

2. Odgovarajući zahtevi po tačkama i podtačkama se razlikuju po strogosti.

3. Regulisanost standardima ili propisima za NVO ili TMS nije uvek potpuna (kreće se od načelnosti, metodologije i sl., pa do propisa-standarda).

se primeni i onda kada se ne radi o uslugama koje su vezane za tehnička sredstva već za bilo koju vrstu usluge.

\section{Zaključak}

Međunarodni standardi, prihvaćeni i kod nas, koji se odnose na sistem kvaliteta nabavki i usluga, za potrebe VJ mogu se i moraju prihvatiti kao minimalni zahtevi i moraju se realizovati kroz sistem nabavki i usluga. Pod uslugama se, pri tome, podrazumeva širi pojam od pojma usluga koje se odnose na tehnička sredstva i tehničke sisteme (zdravstvene, saobraćajne, ugostiteljske, administrativne, energetske, finansijske i sl.).

Identifikacija propisa ili standarda kojim se propisuje način (metodologija) realizacije elemenata (nomenklatura) sistema kvaliteta, u ovom radu nije detaljna i zahteva dalju precizniju razradu i izdavanje odgovarajućih uputstava za primenu datih propisa i standarda VJ.

\section{Literatura:}

[1] Standardi JUS ISO 8402, 9000, 9001, 9002, 9003, 9004, 9004-1, 9004-2, 10011, 10012 i 10013.

[2] Kodžopeljić, J.: Kvalitet i Integralno tehničko obezbeđenje tehničkih sređstava i sistema, VTG br. $5 / 94$.
Deo elemenata sistema kvaliteta (nomenklatura) nije pokriven standardom niti propisom, što znači da nije definisana metodologija za njegovu realizaciju. To se, naročito, odnosi na oblast usluga za koju postoji vrlo malo regulative. $\mathrm{Za}$ elemente sistema kvaliteta koji nisu pokriveni standardima ili propisima VJ, treba uraditi propise ili, ako postoje, prihvatiti inostrane.

Međunarodni standardi sistema kvaliteta predstavljaju minimum zahteva, te za potrebe NVO i usluga za VJ treba ostvarivati šire zahteve i posebno ih regulisati.

Postojeće propise i standarde VJ $\mathrm{u}$ oblasti sistema kvaliteta treba proširivati i prilagođavati međunarodnom sistemu standardizacije.

Metodologija ITOb-a mora se dalje razvijati i usavršavati kao specifična metodologija za tehnička sredstva (i usluge) za potrebe VJ, koja obuhvata i kvalitet, ali definiše i ostale zadatke vojnog sistema koji se odnose na tehnička sredstva i usluge.

[3] Propisi, preporuke i standardi Vojske Jugoslavije: SNO 1096, UPRF-1, SNO 8196, TPR 1783, $1766,1780,1781,1767,1769,1770$, SNO 4264, SNO 0477. 